\title{
The Effect of Changing the Listing Level on the Information Environment of ADRs
}

\author{
Candice L. Deal ${ }^{1}$ \\ ${ }^{1}$ Department of Business Admnistration, Eastern Connecticut State University, Willimantic, Connecticut, USA \\ Correspondence: Dr. Candice L. Deal, Assistant Professor of Accounting, Department of Business Admnistration, \\ Eastern Connecticut State University, Webb Hall 147, Willimantic, Connecticut 06226, USA. Tel: 860-465-0842.
}

Received: May 31, 2016

Accepted: June 15, 2016

Online Published: July 20, 2016

doi:10.5430/ijfr.v7n4p208

URL: http://dx.doi.org/10.5430/ijfr.v7n4p208

\begin{abstract}
This study investigates the impact of changing the listing level of American Depositary Receipts (ADRs) on the information environment of ADRs. Specifically I examine four main listing levels of ADRs and analyze whether ADRs that change (upgrade/downgrade) their listing level have greater/less analyst coverage, increased/decreased forecast accuracy, and increased/decreased forecast dispersion. In addition, since analyst forecast accuracy differs depending on ADRs' home country legal institutions, this study also investigates whether analyst forecast accuracy differs depending on ADRs' home country legal institutions. Specifically, I examine whether the impact on information environment is different for ADRs from countries with different legal systems and disclosure regulations. The SEC has segmented ADRs into four listing levels which have different reporting and regulatory requirements. The SEC and disclosure requirements vary across the four ADR programs. Level II and Level III are exchange listed ADRs, Level I is traded OTC, and Level IV private placement. ADRs that trade in the U.S. market (exchange listed) have more stringent requirements and must adhere to stronger enforcement of accounting standards. Thus, their regulatory and hence quality of information environment is higher. If ADRs that trade on Level II and Level III must follow a more rigorous regulatory requirement, then do analysts and investors in the U.S. markets adjust the pricing of securities to reflect this difference in ADR listing levels? The sample consists of 448 ADR firms from emerging and developed markets around the world that cross-listed on U.S. markets and eventually changed their listing level between 1999 and 2010. I classify the firms based on their listing level which symbolizes the degree of regulatory adherence. To proxy for the information environment, I examine analyst forecast. I analyze the level of significant difference in forecast accuracy, number of analyst forecast, and forecast dispersion when ADRs change their listing level. I present empirical evidence consistent with the hypotheses that an upgrade (downgrade) of ADR listing level is associated with a decrease (increase) in analysts' forecast error, and number of analyst following. These results indicate that a change in the information environment around U.S. cross-listing is a combination of both the bonding hypothesis effect and the ADR listing level effect.
\end{abstract}

Keywords: analyst forecast, ADRs, forecast dispersion, information environment, cross-listing, shareholder protection

\section{Introduction}

There is increasing evidence in the literature that suggests that a country's institutional frameworks play an important role for access to capital (e.g., La Porta et al., 1997; 2000). As a result of this evidence, cross-listing in the U.S. has been viewed as a way for foreign firms from countries with weak institutions to overcome these capital deficiencies (Coffee, 1999; Stulz, 1999). Consistent with this concept, several studies show that cross-listings have significant effects on the foreign firms' market values, using either event study returns (e.g., Forester and Karolyi, 1999) or comparing them with firms that are not cross-listed (e.g., Doidge, 2004, and Doidge et al., 2009).

The existing stream of literature suggests that there are many cross-listing benefits for foreign firms. However, what still remain unknown are the sources of these benefits (e.g., Doidge, 2004). One important question is whether and to what extent cross-listing in the U.S. affects the information environment of these ADRs. The bonding hypothesis proposes that cross-listing in the U.S. increases investor protection (Coffee, 1999; Stulz, 1999), which provides more access to capital for the firm (e.g., Reese and Weisbach, 2002). Moreover, listing on the U.S. capital markets such as on Nasdaq, NYSE, or Amex require these foreign firms to comply with U.S. Securities and Exchange Commission's 
(SEC) disclosure rules, which creates transparency, improve investor recognition, increase the firm's investor base, and eventually result in a lower cost of capital (e.g., Verrecchia, 2001) and a decrease in information asymmetry.

The results of Doidge, Karolyi, and Stulz (2004) support the functional convergence hypothesis, which suggest that cross-listed firms gain by moving from an information environment of poor quality information to one of increased enforcement, and increased disclosure and transparency (Coffee, 2002). This suggests that a foreign firms' information environment should be a function of cross-listing, because the firm is committing to an increased level of disclosure and strict regulations in order to comply with U.S. Generally Accepted Accounting Principles (GAAP) and Securities and Exchange Commission's guidelines (SEC). To date, there is little direct evidence on the relation between a firm's information environment and cross-listing. Thus, it is still an open and interesting question whether U.S. cross-listings improve the information environment of foreign firms.

This study investigates whether the information environment of American Depository Receipts, hereafter ADRs, changes when these ADRs reallocate their listing level. The focus is on the impact of the information environment when the firm decides to cross-list in the U.S. market. I examine the four main levels of ADRs and analyze the impact of upgrading and downgrading the ADR listing level on analyst forecast. Specifically, I examine whether ADRs that upgrade (or downgrade) their listing levels have increased (decreased) forecast accuracy and greater (less) analysts coverage/following. In addition to providing evidence that the analysts forecast accuracy and following differ systematically across regulatory consequences of different types of American Depositary Receipts (ADRs), I also investigate whether the same is true across firms from home countries with different institutional frameworks. I propose that analysts forecast accuracy and the number of analysts following differ depending on firms' home country legal institutions. Thus, I investigate whether these changes in ADR listing levels will be more significant in firms from countries with stronger (weaker) investor protection and also which ADR listing level experience significant changes. I predict that the analysts forecast accuracy changes are stronger and more significant for firms from countries with weaker legal institutions and less extensive disclosure regulation. The finding of this study aims to support existing evidence in the literature on the bonding hypothesis (e.g., Reese and Weisbach, 2002; Doidge, Karolyi, and Stulz, 2004), which several recent studies have questioned (e.g., Siegel, 2005).

The SEC has segmented cross listed firms into four levels based on their degree of SEC requirements. Level II and Level III ADR programs require more stringent reporting and regulatory requirements. These reporting and regulatory requirements must be met under the U.S. Sarbanes-Oxley Act of 2002 (Sarbanes-Oxley) and the U.S. Securities Exchange Act of 1934. I collect a sample of U.S. cross-listings and classify them into exchange listings (Level II and Level III), over-the-counter (Level I) listings and private placements (Level IV), accounting for the different regulatory consequences the firms face. For an exchange listing, firms have to register with the SEC and file Form 20-F, which requires extensive disclosures and a reconciliation of foreign financial statements to U.S. GAAP. Cross-listings in the OTC market do not require a 20-F filing, but a registration statement using Form F-6 and home-country disclosures to the SEC. They are also subject to Rule 10b-5 and the Foreign Corrupt Practices Act, under which most SEC enforcement actions as well as private class action suits are brought (Karpoff, Lee, and Martin, 2008). Private placements under Rule 144A do not require SEC registration or any additional disclosures. Given these regulatory consequences, I hypothesize that, if cross-listings improve the information environment and hence increase analysts' accuracy and following, the effects are strongest for level II and III exchange listings. Therefore, I posit that the regulatory consequences of U.S. cross-listings play an important role, which is consistent with the bonding hypothesis.

I focus on firms cross-listed on US exchanges and examine to what extent these firms show differences in the level of analysts' accuracy and following as a result of differences in their required adoption of regulations based on their ADR listing level. Thus, I provide evidence that the information environment differ across regulatory consequences of different types of ADRs and across firms from home countries with different institutional frameworks.

To empirically examine this, I collect and categorize a sample of 448 ADR firms from emerging and developed markets that cross-listed on U.S. markets between 1999 and 2010. The study aims to understand how the reallocation and change of ADR listing levels impacts analysts' forecast accuracy and following.

\subsection{Background and Motivation}

The motivation for this study hinges on two distinct literatures. First, various studies emphasize the role of information asymmetry and differential information processing by investors in evaluating price and volume reactions to public information announcements which eventually provides investors on the information environment of the firm (Diamond and Verrecchia, 1991; Kim and Verrecchia, 1991; Harris and Raviv, 1993; Kandel and Pearson, 1995). These studies show that the reaction to an earnings announcement is an increasing function of both the magnitude of the price reaction and in the case of this study, the level of information asymmetry among investors. 
There is a large body of literature on international cross-listings (Karolyi, 1998), much of which has focused on why so many non-U.S. firms have pursued them in U.S. markets during the past decade. Particularly, to date, there exist relatively few previous studies on cross-listing that has distinguished between the four different ADRs. Instead, available studies simply distinguish between listed and unlisted programs (e.g., Reese and Weisbach, 2002; Doidge et al., 2009). Distinguishing among ADR programs according to their listed and unlisted character is important, but it does not take into account other differences that exist within these two broad categories. For instance, within unlisted programs, Rule 144A (private placements) provides access to primary US capital markets, while Level I does not. Similarly, within listed programs, Level II provides no access to primary capital markets, while Level III does so through public offerings. These major differences will impact the choice of listing level of a particular ADR. Thus it is important that we consider these four ADR levels individually. How the information environment change after non-U.S. firms list in the U.S. and how the information environment changes after these firms reallocate their ADR listing level can help us to infer how the quality of the information environment has been affected.

Investors may be unaware of or unable to properly adjust for knowledge of the effects of differential regulatory enforcement. Accordingly, this paper focuses on whether analysts and investors in the U.S. markets adjust the pricing of securities to reflect this difference in ADR listing levels. As it appears right now according to the current literature on foreign firms, surprisingly, investors appear to react indiscriminately to cross listed and U.S. firms, regardless of the quality of their home-country legal environment. These results suggest that cross-listed firms may be receiving a "free lunch" - investors treat their earnings equally to those of otherwise equivalent domestic firms, despite their likely lower quality.

The second literature that motivates this study stems from the bonding hypothesis associated with U.S. listings by non-U.S. companies and also the "investor recognition" hypothesis. While a number of different hypotheses have been proposed to explain them, only a few authors have examined the potential importance of changes in the information environment as a factor. Foerster and Karolyi (1999) and Miller (1999) find statistically significant share price effects around U.S. listings and show how these effects are consistent with the "investor recognition" hypothesis of Merton (1987). The investor recognition hypothesis proposes that investors pay a premium for familiar assets: a U.S. listing exposes more shareholders to those shares, the "unfamiliarity discount" dissipates, and stock prices increase. However, these studies at best, only indirectly measure changes in the information environment. Baker, Nofsinger and Weaver (2002) show that the share price reactions for U.S. listings by non-U.S. firms are associated with significant increases in the number of analysts following the stock and in the number of media hits. Lang, Lins, and Miller (2003) find that cross-listed firms achieve greater analyst coverage with improved forecast accuracy and tend to enjoy higher valuations as a result in their home country.

This study proposes to contribute to the relatively small but growing literature on U.S. securities regulation. According to the survey paper by Healy and Palepu (2001), there seems to be an underinvestment in research on the causes and consequences of U.S. disclosure regulation. More importantly, the extant research only focuses on firms that are directly subject to U.S. disclosure regulation and does not consider the potential impact of U.S. regulations on foreign firms that are exempt from such regulation.

Most of the empirical evidence on the economic consequences of increased disclosure has focused on U.S. firms with publicly registered securities under current Generally Accepted Accounting Principles (GAAP). However, this disclosure environment is already saturated, so that commitments to increased levels of disclosure have limited economic impact. In contrast, according to Decker (1994), the disclosure levels mandated by securities market regulators in many other countries have been criticized as relatively low. One important context in which international differences in disclosure standards might matter is when non-U.S. firms choose to list their shares on U.S. exchanges or register their securities with the SEC for a public offering of shares.

This study also contributes to the existing literature on analyst forecasting behavior. I present evidence that investor protection and information environment proxied by ADR level listing requirements is an important factor influencing analyst forecast bias and extends the previous studies that simply focus on prevalent analyst bias in earnings forecasts.

This study also contributes to the ongoing debate surrounding the bonding hypothesis. There appears to be a presumption in the literature that if cross-listed firms are exempt from a U.S. security law, they will not have incentives to voluntarily follow it (Licht 2003). I propose that this presumption does not always hold true due to the "bonding effect" and "information spillover" which suggests that U.S. firms' forced adoption of SOX, REG FD and other U.S. Security laws may also induce cross-listed firms to voluntarily follow these security regulations in order to avoid being labeled by investors as firms with worse information. In the case of regulation FD for example, ADRs are legally exempt from Reg FD but are subject to the same confounding factors as U.S. firms (Francis, Nanda and Wang 2006). 
Although ADRs are legally exempt from Reg FD some ADRs have voluntarily complied with Reg FD (Francis et al. 2006). If this bonding effect presumption holds true, then we would find no significant difference in the information environment between the four ADR listing levels and the information environment would not change if the ADR level changes.

However, Siegel (2005) hypothesized that the bonding role of cross-listing is "overstated". According to Siegel (2005), the impact of US regulations is mitigated by the fact that SEC is less likely to prosecute foreign companies. Siegel (2005) finds that cross-listing in the US did not deter Mexican firm insiders from expropriating corporate resources. Siegel's argument demonstrates that listed ADRs do not always serve as a way to avoid misappropriation. Therefore, if I find that the information environment differs significantly among listing levels, then I can confirm that the bonding hypothesis does not hold true. Thus, this study contributes to the literature by attempting to settle the ongoing debate surrounding the bonding hypothesis.

\subsection{Why Do Firms Cross-List?}

A review of the academic literature identifies several reasons as to why firms cross-list. Some of these motives include a desire for these foreign firms to increase the visibility of the company, to tap into a more liquid market, to signal the company's strength, or to follow tougher exchange requirements. Additionally, firms benefit from cross-listing because it lowers their cost of capital, gives them access to foreign capital markets, increases their ability to raise equity, increases their shareholder base, makes their stock more liquid, and adds visibility, exposure, and prestige (Mittoo, 1992, Fanto and Karmel, 1997).

The main theories underlying the cross-listing decision suggest that companies choose to cross-list in the U.S. to broaden their shareholder base, to increase their visibility, and to credibly signal their commitment to protect minority interests (Stulz, 1999; Coffee, 1999, 2002). Although some of the evidence is consistent with the market segmentation hypothesis (e.g., Foerster and Karolyi, 1999; Miller, 1999), several recent studies question the extent to which market integration alone can explain the cross-listing effects (Doidge, Karolyi, and Stulz, 2004; Karolyi, 2006). The market segmentation argument, however, is not specific to U.S. cross-listings and does not predict that different types of ADRs have differential effects. However, cross-listings on U.S. exchanges (i.e., AMEX, NASDAQ and NYSE) generally have much stronger return effects than either cross-listings in other countries (e.g., Sarkissian and Schill, 2006) or cross-listings in other U.S. markets, such as the Pink Sheets or private placements ( Foerster and Karolyi, 1999; Doidge, Karolyi, and Stulz, 2004).

One explanation for the strong effects of U.S. cross-listings is the bonding hypothesis (Coffee, 1999; Stulz, 1999). It explicitly recognizes the legal consequences of U.S. cross-listings. The idea is that U.S. disclosure requirements, exposure to SEC enforcement, and the threat of shareholder litigation make it harder and more costly for controlling owners and managers to extract private control benefits from outside investors. Thus, cross-listing in the U.S. provides a means to controlling insiders from countries with weak governance structures to credibly commit not to expropriate outside investors. Several recent studies support this argument. Reese and Weisbach (2002) show that, after cross-listing in the U.S., firms raise more external capital, but mostly in their home markets. Doidge, Karolyi, and Stulz (2004) show that firms with U.S. cross-listings exhibit a valuation premium relative to non-cross-listed firms and that the premium is most pronounced for U.S. exchange listings. They also show that the valuation effects combining all ADR types are stronger for firms from countries where investor protection is weaker.

Siegel (2005) however believes that the bonding role of cross-listing is overstated. Siegel (2005), suggests that the SEC's written rules have not been applied to the same extent to cross-listed firms as to domestic firms. According to Siegel, the SEC has rarely taken action against a foreign firm listed in the US. Therefore according to Siegel, added investor protection may be illusory. Based on Siegel's argument, it seems that cross-listing may not reduce the incidence of earnings management by foreign firms and thus, the information environment and quality of ADRs may not improve when these firms decide to cross-list.

\subsubsection{ADR Listing Levels}

This study considers American Depositary Receipts (ADRs). Non-U.S. companies must satisfy two primary requirements to be listed in the U.S. regardless of the form of listing. First, they must arrange with a transfer agent and registrar appropriate settlement facilities that can coordinate with the home market. Second, the company must file a registration statement with the SEC and furnish an annual report on a Form 20-F with a reconciliation with U.S. GAAP.

Any firm that cross-lists via an ADR have basically four options to choose from: Level I, Level II, Level III, and Level IV (Rule 144A) programs, all of which have distinct attributes. Level I ADRs trade over-the-counter on the 
OTC Bulletin Board or as a "pink sheet" issue with limited liquidity, but they require only minimal SEC disclosure and no GAAP reconciliation (exempt from Form 20-F by Rule 12g3-2(b)). Level II and III ADRs are exchange listed securities and they can be traded on the New York Stock Exchange (NYSE), the National Association of Securities Dealers Automated Quotation System (NASDAQ), or the American Stock Exchange (AMEX). Level II and III ADRs require full SEC disclosure with Form 20-F. Level III programs raise capital and must file Form F-2 and F-3 for offerings. Finally, SEC Level IV (Rule 144A) issues raise capital as private placements to qualified institutional buyers (QIBs) and do not require compliance with GAAP. Level IV (Rule 144A) programs trade on the PORTAL system, the NASD's quotation system for Level IV (Rule 144A) securities.

Level III and Level IV give these ADRs access to the US primary capital markets which means that they are able to raise capital. Levels I and II on the other hand allows these firms access to US secondary markets only and hence they are not able to raise initial capital. The governance and disclosure requirements vary across the four ADR programs as well. Governance and disclosure requirements are more restrictive in Levels II and III (listed programs) than in Level I and Level IV (unlisted programs). The four types of ADRs and their different features are summarized in table 1which was adapted from Boubakri et al (2010).

Table 1. Characteristics and features of ADRs

\begin{tabular}{|c|c|c|c|c|}
\hline & $\begin{array}{c}\text { Level I } \\
\text { (unlisted) }\end{array}$ & Level II (listed) & Level III (listed) & $\begin{array}{c}\text { Level IV-Rule 144A } \\
\text { (unlisted) }\end{array}$ \\
\hline Where traded & OTC & $\begin{array}{c}\text { NYSE-NASDA } \\
\text { Q-AMEX }\end{array}$ & $\begin{array}{l}\text { NYSE-NASDAQ- } \\
\text { AMEX }\end{array}$ & $\begin{array}{c}\text { Trading through automated } \\
\text { linkages (PORTAL) }\end{array}$ \\
\hline $\begin{array}{l}\text { Ability to raise } \\
\text { capital }\end{array}$ & NO & NO & $\begin{array}{l}\text { YES (public } \\
\text { offerings) }\end{array}$ & $\begin{array}{l}\text { YES(private placements } \\
\text { among Qualified } \\
\text { Institutional Buyers) }\end{array}$ \\
\hline Objective & $\begin{array}{l}\text { Develop and } \\
\text { broaden US } \\
\text { investor base } \\
\text { with existing } \\
\text { shares }\end{array}$ & $\begin{array}{c}\text { Develop and } \\
\text { broaden US } \\
\text { investor base } \\
\text { with existing } \\
\text { shares }\end{array}$ & $\begin{array}{c}\text { Develop and } \\
\text { broaden US } \\
\text { investor base with } \\
\text { existing \& new } \\
\text { shares }\end{array}$ & $\begin{array}{l}\text { Tap into QIB (institutional } \\
\text { investors) }\end{array}$ \\
\hline $\begin{array}{l}\text { Accounting } \\
\text { requirements }\end{array}$ & $\begin{array}{l}\text { Home } \\
\text { market }\end{array}$ & $\begin{array}{c}\text { Partial } \\
\text { reconciliation } \\
\text { with US GAAP } \\
\end{array}$ & $\begin{array}{l}\text { Full reconciliation } \\
\text { with US GAAP }\end{array}$ & Home market \\
\hline $\begin{array}{l}\text { US reporting } \\
\text { requirements }\end{array}$ & $\begin{array}{c}\text { Exempt } \\
\text { from filing } \\
\text { form } 20-\mathrm{F} \\
\text { under Rule } \\
12 \mathrm{~g} 3-2(\mathrm{~b})\end{array}$ & Form 20-F & Form 20-F & $\begin{array}{l}\text { Exempt from filing form } \\
\qquad 20-\mathrm{F} \\
\text { under Rule } 144\end{array}$ \\
\hline $\begin{array}{c}S E C \\
\text { registration }\end{array}$ & Form F-6 & Form F-6 & Form F-1 and F-6 & NONE \\
\hline $\begin{array}{c}\text { Adherence to } \\
\text { SOX }\end{array}$ & N/A & Applicable & Applicable & $\mathrm{N} / \mathrm{A}$ \\
\hline $\begin{array}{l}\text { Size \& earnings } \\
\text { requirements }\end{array}$ & NONE & YES & YES & NONE \\
\hline Listing fees & LOW & HIGH & HIGH & LOW \\
\hline
\end{tabular}

Sources: (a) Bank of New York, (b) ADR Universe, (c) Boubakri, Cosset, and Samet, 2010

\subsubsection{The Choice of ADRs}

According to Boubakri et al. (2010), the choice of a specific ADR is of primary importance for both practical and theoretical grounds. In practice, this choice has implications for the firm's future financing decisions, corporate governance, and US investor base. More precisely, (1) it affects the firm's access to US capital (i.e., its financing decision) by private placements (Rule 144A) or public offerings (Level III); (2) The choice of a particular ADR (listed versus unlisted) also affects the firm's corporate governance, as listed programs (i.e., Level II or Level III) commit the firms to higher governance, disclosure, and accounting standards; and (3) Moreover, by choosing Levels 
I, II, and III, foreign firms develop and broaden their US investor base by using either their existing shares (Levels I and II) or by issuing new ones (Level III) (Boubakri et al. 2010).

A number of recent studies focused on the costs and benefits associated with SOX compliance. As a result of the additional costs associated with SOX compliance, a considerable number of US public firms delisted from US exchanges, deregistered from the SEC and "went dark" (Leuz et al., 2008; Engel et al., 2007). Similarly, voluntary delisting of foreign firms that are listed on US markets increased significantly after 2002 (Marosi and Massoud, 2007; Witmer, 2006). In contrast, the inflow of ADR cross-listings showed no signs of slowing down in the post-SOX period, compared to the pre-Sox period. SOX may have, however, led to a reallocation among the four ADR programs since this new regulation did not affect all ADR programs alike. Only firms issuing Level II and Level III ADR programs, which require a registration with the SEC, have to comply with the new SOX rules of disclosure and governance. Level I and Level IV ADRs, which are both unlisted programs, are exempt from SOX requirements.

Boubakri et al. (2010) compared the percentage of each ADR program from pre and post-SOX periods. They find that the share of capital-raising programs (i.e., Rule 144A and Level III) increases in the post-SOX compared to the pre-SOX period. Boubakri et al. (2010) found that in the post-SOX period, 30.4\% of all ADRs are issued as Rule $144 \mathrm{~A}$ as compared to $12.7 \%$ in the pre-SOX period, and Level III programs attract $15.7 \%$ of the total ADRs in the post-SOX period compared to $10.3 \%$ in the pre-SOX. They also find that the proportion of Level II ADRs decreased in the post-SOX period, dropping from $27.1 \%$ to $14.4 \%$. Likewise, firms issue relatively fewer Level I ADRs in the post- SOX period, decreasing from $41.9 \%$ to $39.5 \%$.

Boubakri et al. (2010), show that a firm that issues an ADR after April 24, 2002 is more likely to issue Rule 144A and less likely to choose Level II. According to the findings of Boubakri et al. (2010), fifty-seven percent of the Rule 144A ADRs are issued after the implementation of SOX. This result is consistent with Zingales' (2006) evidence. His shows the large increase in the number of 144A registrations by foreign firms after SOX which, by allowing them to avoid US legal liability, helps them tap the US markets via the "back door."

Boubakri et al. (2010) also found that firms from emerging market countries are more likely to choose Rule 144A in the post-SOX period. They show that being an emerging market firm increases the probability of choosing Rule 144A in the post-SOX period. The evidence that firms from emerging markets are more willing to issue Rule 144A ADRs after SOX was enacted is consistent with Lins et al.'s (2005) and Zingales' (2006) findings that emerging market firms that are faced with more financial constraints than are developed country firms need to raise more external capital on US markets, and are able to do so through Rule 144A (private placements) or Level III (public offerings). As Level III becomes costly after SOX, especially for emerging markets firms, these latter become more inclined to issue a Rule 144A ADR (less costly program), and raise external capital on US markets among Qualified Institutional Buyers.

Also, the percentage of emerging market firms selecting Level I is smaller in the post-SOX period. They also observe an increase in Level III ADRs in the post- SOX period. More precisely, firms from countries where the legal protection of minority shareholders is weak (compared to the US) are more willing to issue Level III programs in the post-SOX period than in the pre-SOX one, despite the additional costs implied by the SOX Act for this level.

\subsection{The U.S. Regulatory Environment- Disclosures and Analyst Following}

Studies such as Ball et al. (2000) suggest that managers of foreign firms face stronger incentives to manage earnings either due to different structure in corporate governance or simply opportunities offered by a weak local regulatory environment. Based on the incentives and counter-incentives to manage earnings as found in prior research, it seems that cross-listing may not reduce the incidence of earnings management by foreign firms. To mitigate these costs, foreign firms can cross-list their securities in markets with greater regulatory oversight. This is the "legal bonding hypothesis" described by Coffee (2002), in which cross-listing in the U.S. is seen as a way for foreign firms to effectively subject themselves to U.S. securities laws and the corresponding increased disclosure and investor protection these laws afford investors. However, SEC enforcement of violations of securities laws by cross-listed firms has been relatively uncommon. As a result, cross-listing may permit foreign firms to improve their reputations, increase their firms' shareholder bases, and benefit (by association) from the strong legal environment and dynamic U.S. capital markets with a fairly low likelihood of being held accountable for aggressive financial reporting.

The bonding hypothesis suggests that all firms in the U.S. would comply with U.S. regulations and that cross-listing in the US stock market can serve as a bonding mechanism for foreign corporate managers and should increase transparency in corporate governance, resulting in high quality of accounting information. Recent studies however, such as Licht (2003) and Siegel (2005), hypothesize that the bonding role of cross-listing is overstated. According to 
Siegel (2005), the impact of US regulations is mitigated by the fact that SEC is less likely to prosecute foreign companies. Siegel (2005) examine SEC disclosure enforcements and are unable to find any cases in which disclosure violations by non-US issuers have been tested in court or have been subject to formal investigation or administrative proceedings. In particular, Siegel (2005) conducts an exhaustive review of all SEC litigation from 1995 to 2002 and finds only 13 cases that SEC prosecuted against cross-listed firms, often unsuccessfully.

Given the false presumption of the bonding hypothesis and the absence of the enforcement and litigation against cross-listed firms, there may be a possibility that managers of cross-listed non-US firms face increased incentives to manage earnings to achieve their personal goals. So the question becomes whether these ADRs truly bonded and still adhere to certain U.S. regulations even though their listing level does not require them to?

Cross-listing on a U.S. exchange commits foreign firms to disclosure rules that are generally more extensive and more strictly enforced than in their home country. Consistent with this claim, empirical studies find significant changes in firms' information environments around U.S. cross-listings indicating an increase in disclosure quality (e.g., Lang, Lins, and Miller, 2003; Bailey, Karolyi, and Salva, 2006). These information effects can reduce information asymmetries and lower firms' costs of capital (Verrecchia, 2001; Lambert, Leuz, and Verrecchia, 2007; Stulz, 2008). Several recent studies provide evidence that a U.S. cross-listing improves a firm's recognition in the media and by financial analysts, and that it broadens the investor base (Baker, Nofsinger, and Weaver, 2002; Lang, Lins, and Miller, 2003).

\subsection{Literature Review and Hypotheses}

Foreign firms may upgrade their listing level because an upgrade increases their ability to raise equity at a lower cost of capital, increases their shareholder base, makes their security more liquid, and adds transparency and prestige (Mittoo, 1992, Fanto and Karmel, 1997). Forecast accuracy is positively associated with disclosure/regulatory level and the enforcement of accounting standards, suggesting that managers are more likely to follow prescribed accounting rules when they know that their accounting choices are better monitored (i.e. the 'accounting uncertainty' facing analysts is reduced).Lang and Lundholm (1996) show that firms disclosing more have more accurate and less dispersed analyst earnings forecasts. One dimension that has not yet been explored in this body of research regarding the regulatory environment and analysts forecasts is if the results found by Lang and Lundholm (1996) can be generalized to cross listed firms in the U.S. i.e., if disclosure has the same effect in reducing the dispersion of analysts' earnings forecasts and improving earnings quality in both cross listed firms and U.S. firms. The rationale behind this is that although these all of these cross listed firms operates in the same U.S. capital markets, Level IV ADRs are exempted from certain U.S. securities laws.

Prior research suggests that the resultant improvement in disclosure quality and transparency would reduce the cost for a disclosure intermediary to acquire information. In fact, Lang, Lins, and Miller (2003) find that the improved information environment associated with cross listing increases the accuracy of analyst forecasts of earnings. This issue is motivated by the economic theory that greater disclosure lowers the information asymmetry (e.g., Glosten and Milgrom 1985 and Diamond and Verricchia 1991) and the estimation risk (e.g., Barry and Brown 1985).

I expect managers to follow prescribed accounting and disclosure rules to a greater extent when they upgrade their listing level and hence enforcement is stronger. To the extent that upgrading increases transparency and disclosures and disclosures are informative about a firms' prospects and accounting practices, and to the extent that analysts actually rely on disclosures in the annual report, enhanced disclosure proxied by a listing upgrade should be associated with greater earnings forecast accuracy. Forecast dispersion has frequently been used as a proxy for information asymmetry (Lang and Lundholm 1996, Barron and Stuerke 1998). High dispersion implies low consensus among analyst forecasts and consequently high information asymmetry. If downgrading causes firms to reduce the quantity and quality of available information, then analysts will be forced to rely more on their own research and obtain more selective disclosure. Spending more time on individually researching firms and reaching varied conclusions should lead to higher forecast dispersion when ADR firms downgrade their listing level. This argument is consistent with the results in Barron, Kim, Lim and Stevens (1998), which shows that dispersion captures the extent to which private information differs across analysts. This leads to the following hypotheses:

H1: An upgrade (downgrade) of ADR listing level is associated with a decrease (increase) in analysts' forecast error

Using conference call data from the pre-FD era, Bowen, Davis and Matsumoto (2002) finds that information availability is negatively correlated with analyst forecast dispersion. Consequently, if downgrading reduces the quantity and quality of firm-specific information available to all market participants, then we expect lower consensus among analysts and higher forecast dispersion. Further, if analysts now have to spend more time researching a firm 
because of lack of transparency and no disclosure requirements, then the average number of analysts following a firm will also decrease when ADRs downgrade their listing levels. Hence, I derive the following hypothesis:

H2: An upgrade (downgrade) of ADR listing level is associated with an increase (decrease) in the number of analysts' following

Forecast errors are used to judge the public information quality. On the other hand, forecast dispersion is used to judge the private information quality (Barron et al. (2002), Gu (2004)). Forecast dispersion is the standard deviation of analysts' forecasts deflated by the stock price. This measure accounts for the disagreement among analysts, which can result from lack of available information about the firm. Hence, larger information asymmetry is expected to be associated with greater dispersion. I derive the following hypothesis to examine analysts' forecast dispersion:

H3: An upgrade (downgrade) of ADR listing level is associated with a decrease (increase) in analysts' forecast dispersion

\subsubsection{Analysts' Forecast Behavior \& Shareholder Protection}

I extend the analyses of the relation between the information environment and U.S. cross-listings by examining whether the cross-listing effect on the information environment differs by home-country legal institutions. Coffee (2002) views the increasing incidence of cross-listing as a "race towards the top" where more foreign firms are embracing stricter legal requirements in order to raise equity capital and increase shareholder base. Coffee identifies two types of firms: firms from already strong legal environments and firms from weak legal environments. He argues that the objective of cross-listing is somewhat different for these two types of firms. In effect, a firm from an already strong legal environment might choose to cross-list in the US markets in order to gain a currency advantage for potential stock-for-stock transactions or acquisitions of US companies. However, for a firm from a weak legal environment, cross-listing seems to be more in line with a "legal bonding" hypothesis where a firm is subjecting themselves to US market securities laws. Such a move entails greater disclosure and potentially stricter enforcement and can therefore benefit foreign firms by strengthening their reputation, which in turn will help attract more investors who would otherwise be reluctant to invest.

A similar argument is advanced by Reese and Weisbach (2002), who see cross listing as a tool for managements of firms in weak legal environments to protect their minority shareholders. By cross-listing in the US, those firms can offer a greater level of protection to their minority shareholders by giving them the ability to free-ride on shareholder lawsuits of US shareholders for fraudulent statements made anywhere in the world. Lang, Lins and Miller (2002) provide evidence that cross listing increases a firm value by enhancing its information environment. They show that firms that cross-list on US exchanges enjoy greater analyst coverage and an increase in forecast accuracy compared to firms that do not cross-list.

Under the bonding hypothesis, I expect cross-listing effects to be stronger for firms originating from countries with weaker legal institutions. Thus, in addition to testing for the magnitude of change in analysts' forecast accuracy and the change in the number of analysts who cover the stock, we identify the type of ADR listing pursued by the company and the rigor of home-country accounting and disclosure standards to capture the magnitude of the change in the information environment when the listing levels change. Therefore, this current study also provides evidence that analysts under different shareholder protection systems display distinctive characteristics of forecast bias.

In countries where legal protections for minority shareholders are weak, it is considerably difficult for a firm to raise external capital. Thus, the convergence hypothesis states that firms wishing to raise outside capital respond to this difficulty by voluntarily bonding themselves to protect the interests of their minority shareholders. One way to accomplish this bonding is cross-listing in the United States whose legal system protects minority shareholder interests better than any other country in the world.

Drawing on the classification scheme of La Porta et al. (1998), I construct a dummy variable for countries - strong and weak. The portfolio "strong" stands for the strong shareholder protection, while the portfolio "weak" denotes the weak shareholder protection. The analysis is performed separately for the cross-listed non-US firms from high investor protection legal environments and for those from low investor protection legal environments.

For companies that choose/change to exchange listings (Level 2 or 3 ADRs) and for those that list in the U.S. from countries with relatively poor accounting standards (weak shareholder protection), we expect a more dramatic decrease in analysts' forecast dispersion than for companies that choose OTC listings or Rule 144a private placements and for those that list from countries with relatively good accounting standards (strong shareholder protection). 
Thus, I attempt to capture the extent to which the institutional framework in the home country protects outside investors and, consequently, the extent to which firms benefit from being subject to U.S. regulation and markets. Based on the preceding information, I derive the following hypotheses:

H4a: ADRs from civil law countries would experience a higher net effect associated with a change of listing level than ADRs from common law countries.

H4b: ADRs from weak investor protection countries would experience a higher net effect associated with a change of listing level than ADRs from strong shareholder protection countries.

\section{Research Design, Methodology and Data}

I obtain details on foreign firms listing in the U.S. (NYSE, NASDAQ, AMEX, over-the counter) with a depositary receipt (ADR) or ordinary listing using information from Citibank (CB), JP Morgan (JPM), Deutsche Bank (DB), and Bank of New York (BNY). The sample includes only sponsored ADRs because unsponsored ADRs are created on investors' initiatives (primarily institutional investors), independently from the manager/controlling shareholder's preferences for a particular ADR program.

I compile a comprehensive data set of active and inactive U.S. cross-listings. Bank of New York alone accounts for $49.3 \%$ of the ADR market. (Note 1) I downloaded valuable information from these depositaries' websites regarding ADRs. (Note 2) I exclude the "side by side" ADR programs. Under this program, the company establishes a public Level I ADR program as well as a private Rule 144A ADR for the same class of stock. This structure allows companies to combine the benefits of publicly traded programs with the possibility of raising capital.

Next, I obtain analyst forecasts and share price information from $I / B / E / S$. I download all firms contained in the above mentioned ADR database from 1999-2010. Due to different legal and regulatory consequences, I differentiate between exchange listings on NYSE, NASDAQ, and AMEX, over-the-counter listings in the Pink Sheets or the OTC Bulletin Board, and private placements under Rule 144A. I differentiate between ADR types: (1) exchange listings on NYSE, Nasdaq, and Amex (EXCH), (2) over-the-counter listings in the Pink Sheets or the OTC Bulletin Board (OTC), and (3) private placements under Rule 144A $(P P)$. This distinction reflects different regulatory consequences. Foreign firms with a U.S. exchange listing (Level I and II) have to file Form 20-F with the SEC, requiring extensive disclosures and a reconciliation of foreign financial statements to U.S. GAAP. Moreover, by virtue of filing with the SEC, firms are subject to SEC enforcement and could face legal liabilities from shareholder litigation. Cross-listings in the OTC markets do not require a 20-F filing, but have to file a registration statement using Form F-6 and home-country disclosures to the SEC. They are also subject to Rule 10b-5 and the Foreign Corrupt Practices Act, under which SEC enforcement actions and private securities litigation can be brought. Private placements under Rule 144A do not require SEC registration or any additional (public) disclosures but are only made available to qualified institutional investors.

Given these regulatory consequences, I hypothesize that, if cross-listings increase analysts' accuracy \& following, the effects are strongest for exchange listings, and it is not clear that private placements should experience any reduction. One possible explanation for private placements not experiencing any benefits is that private placements entail private communication with a small group of institutional investors, which could exacerbate information asymmetries among traders.

Earnings announcements and forecasts are collected from the Institutional Brokers Estimate System (I/B/E/S) tapes. The frequency of earnings information releases varies through countries and firms. For cross-country consistency, I use annual earnings announcements: they maximize the number of events over the widest range of countries. The absolute earnings surprise equals the absolute value of the difference between actual earnings and the mean of the most recent analyst forecasts normalized by the mean forecast. To calculate the mean forecast, I take the last estimate for each analyst reporting forecasts for the current fiscal year.

The rank order of the increase in analysts' accuracy \& following effects (from exchange listings to private placements) suggests that the regulatory consequences of U.S. cross-listings play an important role, which is consistent with the bonding hypothesis. Further corroborating this notion, I propose that the increase in analysts' accuracy \& following for exchange listings is larger for firms from countries with weaker disclosure regulation and weaker protection against self-dealing by corporate insiders.

Analyst following is the number of analysts reporting to IBES, averaged over fiscal months. Total number of outstanding earnings estimates at the end of each month is the measure for analyst following. 
Forecast error is measured as the absolute value of actual analyst forecast minus the mean analyst forecast standardized by the actual analyst forecast. When actual earning is zero, FERROR is not deleted from the sample. It still provides represents information on earnings forecast and it also represents unbiased forecast. One study suggested standardizing the forecast error numerator by stock prices because stock prices cannot be zero. However, in this study I deflate forecast error by actual earnings to avoid including the volatility of stock prices in this study.

Consistent with prior research, I measure accuracy as the absolute value of forecast error:

\section{|Actual EPS - Forecasted EPS|}

Analyst forecast dispersion for each firm is computed as the standard deviation of the most recent forecasts divided by the firm's stock price at the beginning of each period.

Both forecasted and actual earnings per share are from IBES Domestic and International Summary Files. Forecast accuracy is computed as the average of the measure across the months included in the testing window (see Lang and Lundholm 1996). I test the above implications using both univariate and multivariate tests. Using analyst forecast data provided by $\mathrm{I} / \mathrm{B} / \mathrm{E} / \mathrm{S}$, the univariate tests compare the monthly means and medians of forecast dispersion and analyst following.

\subsection{Control Variables}

I also control for other firm- and country-level factors that may impact on the accuracy of analysts' earnings forecasts. Thus I control for firm and country characteristics known to affect analyst forecast by controlling for traditional risk and country factors.

First, I include a number of control variables for risk at the firm level. Based on prior studies, I expect the forecast error to exhibit a negative association with firm size and positive associations with return variability and financial leverage (e.g., Fama and French, 1992, 1993). I measure SIZE as the log of total assets (in US\$ million) at the end of the fiscal year. Firm size has been used in the literature as a proxy for a number of factors. Larger firms are likely to have more analysts covering them. (Bhushan, 1989 and Brennan and Hughes, 1991). To the extent that size reflects information availability about a firm (other than through annual reports), a positive relation with forecast accuracy is expected.

I also include financial leverage (LEV) as the ratio of total assets to total liabilities. I include financial leverage as a third firm-level control because it is known to have a systematic effect on the equity cost of capital (Modigliani and Miller, 1958).

I also use industry- and country-fixed effects in the regression models. I use the industry classification in Campbell (1996) to construct industry indicators. However, the results are also robust to using two-digit Standard Industrial Classification (SIC) codes instead.

\subsection{Country Characteristics}

As a benefit of cross-listing in the U.S., the improvement in information environment of foreign firms may be associated with their home country characteristics. In particular, we analyze whether the improvement in forecast error, forecast dispersion, and number of analyst coverage is related to the ADRs' home country characteristics. The information disclosure explanation for cross-listing benefits (Cantale, 1996; Fuerst, 1998; Moel, 1999) predicts a relation between the information environment variable and the quality and quantity of accounting standards and disclosure rules of the home country of cross-listing firms. I use two measures to capture the level of information disclosure of the home country: country of origin (ORIGIN) and investor protection (COUNTRY).

The minority shareholders' rights protection explanation for cross-listing benefits (Fuerst, 1998; LaPorta et al., 1997, 1998, 2000; Reese and Weisbach, 2002) postulates that foreign firms from weaker legal systems would experience greater improvement in their information environment upon cross-listing in the U.S. I use two measures to capture the level of information disclosure of the home country: country of origin (ORIGIN) and investor protection (COUNTRY).

I measure country of origin as a dummy variable for whether the foreign firm is from a country with English common law tradition (ORIGIN). La Porta et al. (1997, 1998, 2000) show that the protection of minority shareholders' rights is stronger in countries with English common law tradition than in countries with civil law tradition. The indicator variable, LEGAL, equals one for the home country of listing firms that adopt English common law as its legal origin of the company, and zero if the firm is from a country that adopts civil law as its legal origin. 
I measure investor protection (SHRPROTECTION) as a dummy variable for whether the foreign firm is from a country with weak investor protection or strong investor protection. The indicator variable, SHRPROTECTION, equals one if the ADRs originate from a weak investor protection home country and zero if the ADRs originate from a strong investor protection home country. I hypothesize that firms which originate from countries with weaker protection for minority shareholders, i.e., those coming from civil law tradition, experience greater visibility and lower dispersion of recommendations upon their cross-listing in the U.S. Table 2 defines these control, country, and other variables used in this study.

Table 2. Variable descriptions

\begin{tabular}{|c|c|}
\hline & Definition of Variables \\
\hline Level IV & Private Placements - ADRs listed on level 4 \\
\hline Level I & Over the Counter - ADRs listed on level 1 \\
\hline Level II & ADRs listed on level 2 - Exchange traded ADRs \\
\hline Level III & ADRs listed on level 3 - Exchange traded ADRs \\
\hline UP & ADRs that upgraded their listing level \\
\hline DOWN & ADRs that downgraded their listing level \\
\hline CHANGE & $\begin{array}{l}\text { Dummy Variables: } \\
\text { UP1 = Chg from Level } 4 \text { - Level } 1 \\
\text { UP2 = Chg from Level } 4-\text { Level } 2 \\
\text { UP3 = Chg from Level } 4 \text { - Level } 3 \\
\text { UP4 = Chg from Level } 1 \text { - Level } 2 \\
\text { UP5 = Chg from Level } 1 \text { - Level } 3 \\
\text { UP6 = Chg from Level } 2-\text { Level } 3 \\
\text { Down } 7=\text { Chg from Level } 2 \text { - Level } 1 \\
\text { Down } 8=\text { Chg from Level } 3-\text { Level } 1\end{array}$ \\
\hline FERROR & Analyst Forecast Error: $\mid$ Actual - Mean Analyst Forecast ${ }_{t} \mid /$ Actual \\
\hline FORDISP & $\begin{array}{l}\text { Standard deviation of analyst forecasts for a particular company for a specific } \\
\text { month, standardized by the absolute value of the mean analyst forecast for this } \\
\text { company for that month. }\end{array}$ \\
\hline NUM & The number of analysts following a firm \\
\hline MVE & The natural log of the ADR's market value of equity \\
\hline SIZE & Total assets - larger firms attract more analysts following \\
\hline IND & ADR GICS industry group listing \\
\hline LEV & Total Assets/Total Liability \\
\hline LEGAL & $\mathrm{ADR}=1$ if common law; $\mathrm{ADR}=0$ if civil law \\
\hline SHRPROTECTION & $\mathrm{ADR}=1$ if Weak; $\mathrm{ADR}=0$ if Strong \\
\hline YEAR & $\begin{array}{l}\text { Whether the change in listing level occurred before or after the implementation } \\
\text { of SOX in 2002. ADR }=1 \text { if change occurred after April 2002; ADR }=0 \text { if } \\
\text { change occurred before April } 2002\end{array}$ \\
\hline
\end{tabular}




\subsection{Multivariate Regression}

I examine the roles of analysts' forecasts in explaining the changes in the information environment of foreign firms surrounding their change in listing levels in the U.S. in a multivariate framework. For each change in ADR level, I regress the forecast error, and forecast dispersion on a set of independent variables that proxy for both the degree of information disclosure requirements of cross-listing venues and the level of information asymmetry of foreign firms.

To test $H 1$, whether an upgrade (downgrade) of ADR listing level is associated with a decrease (increase) in analysts' forecast error, I estimate the following regression model:

$$
\begin{gathered}
\triangle F E R R O R_{t}=B_{0}+B_{1} \mathrm{CHANGE}_{\mathrm{it}}+B_{2} \mathrm{SIZE}+B_{3} I N D+B_{4} N U M_{t}+B_{5} M V E_{t}+B_{6} \mathrm{LEV}_{\mathrm{it}}+B_{7} \mathrm{LEGAL}_{\mathrm{it}}+ \\
B_{8} \mathrm{SHRPROTECTION}_{\mathrm{it}}
\end{gathered}
$$

Where:

- $\quad F E R R O R_{t}=\mid$ Actual - Mean Analyst Forecast $t_{\mathrm{t}} \mid$ Actual

- $N U M_{t}=$ the number of analysts providing earnings forecasts

- $M V E_{t}=$ the natural log of the ADR's market value of equity measured in millions of US dollars

Prior research examining analyst earnings forecast accuracy argues for controlling for differences in disclosure levels across firms. Following Lang and Lundholm (1996), I use the extent of analyst following (NUM) to control for differences in firms' disclosure practices that can impact analyst earnings forecasts. A negative coefficient on NUM suggests that analyst earnings forecast accuracy improves (i.e., forecast errors fall in absolute value) as more analysts follow a firm. I use MVE to control for differential information due to firm size. A negative coefficient on MVE suggests that analysts can predict the earnings of larger firms more accurately.

Thus to test H2: i.e., An upgrade (downgrade) of ADR listing level is associated with an increase (decrease) in the number of analysts' following, I estimate the following regression model:

$\Delta N U M_{t}=B_{0}+B_{1} \mathrm{CHANGE}_{\mathrm{it}}+B_{2} S I Z E+B_{3} I N D+B_{4} N U M_{t}+B_{5} M V E_{t}+B_{6} \mathrm{LEV}_{\mathrm{it}}+B_{7} \mathrm{LEGAL}_{\mathrm{it}}+B_{8} \mathrm{SHRPROTECTION}_{\mathrm{it}}$

I measure the dispersion of recommendations with the coefficient of variation of analysts' recommendation ratings, i.e., the standard deviation of recommendation ratings divided by the mean recommendation. IBES Recommendations are coded in a $1-5$ scale where $1=$ strong buy, $2=$ buy, $3=$ hold, $4=$ sell, and $5=$ strong sell. To test H3, i.e., the analyst forecast dispersion is negatively (positively) associated with an upgrade (downgrade) of ADR listing level, I estimate the following regression model:

$$
\begin{aligned}
\Delta \text { ForDisp }_{i t}=B_{0}+B_{1} \mathrm{CHANGE}_{\mathrm{it}}+ & B_{2} \mathrm{SIZE}+B_{3} I N D+B_{4} N U M_{t}+B_{5} M V E_{t}+B_{6} \mathrm{LEV}_{\mathrm{it}}+B_{7} \mathrm{LEGAL}_{\mathrm{it}}+ \\
& B_{8} \mathrm{SHRPROTECTION}_{\mathrm{it}}
\end{aligned}
$$

To proxy for the institutional environment and investor protection, I use law-based variables, legal origin and shareholder protection from La Porta et al. $(1998,2003)$.

- Legal Origin (LEGAL)

- Common Law $=1$

- Civil Law $=0$

- Shareholder Protection (SHRPROTECTION)

- Weak Shareholder Protection =1

- Strong Shareholder Protection $=0$

\section{Descriptive Statistics and Empirical Results}

The data set of U.S. cross-listings was obtained from Citibank, JP Morgan, and Bank of New York ADR Database. I differentiate between 4 ADR types:

- (1) over-the-counter listings in the Pink Sheets or the OTC Bulletin Board (OTC), Level I

- (2) exchange listings on NYSE, Nasdaq, and Amex, Level II \& III

- (3) private placements under Rule 144A (PP) Level IV

This yielded 2093 ADRs from depositary banks' DR Universe between years $1992-2010$. Out of the full sample of ADR firms, I researched to determine which ADRs actually changed their listing level during the sample period. This yielded a total of 448 firms that changed their listing level. Table 3 shows the distribution of firms that upgraded and downgraded and the level to which the firm changed to and from. According to Table 3, the majority of changes 
(36.6\%) occurred with firms upgrading from Level 1 to Level III. The lowest number of changes $(0.45 \%)$ occurred with firms upgrading from Level IV to Level II. Firms downgrading from Level II to Level I and from Level III to Level I represented $19.4 \%$ and $18.9 \%$, respectively, of the ADR changes sample.

Table 3. ADR listing changes-upgrades and downgrades

\begin{tabular}{l|l|clcc}
\hline $\begin{array}{c}\text { UPGRADES } \\
\text { FROM }\end{array}$ & \multicolumn{1}{c}{ TO } & $\begin{array}{c}\text { \# OF } \\
\text { CHANGES }\end{array}$ & $\begin{array}{c}\text { DOWNGRADES } \\
\text { FROM }\end{array}$ & TO & $\begin{array}{c}\text { \# OF } \\
\text { CHANGES }\end{array}$ \\
\hline Level 4 & Level I & 18 & Level II & Level I & 87 \\
\hline Level 4 & Level II & 2 & Level III & Level I & 85 \\
\hline Level 4 & Level III & 56 & & & \\
\hline Level I & Level II & 23 & & & \\
\hline Level I & Level III & 164 & & & $\mathbf{1 7 2}$ \\
\hline Level II & Level III & 13 & & & \\
\hline TOTAL & & $\mathbf{2 6 7}$ & & & \\
\hline
\end{tabular}

Level I - traded OTC; Level II - Exchange traded /no IPOs; Level III - Exchange traded/IPOs; Level IV - Private Placement.

Table 4 presents the distribution of firms by year according to how many firms upgraded or downgraded during that year. In the year 2000, 62 firms underwent a change in their listing level. Out of the total 62 changes, 58 were upgrades. In 2001, 51 firms made a change to their listing level. Of the total changes made that year, 46 of these changes were upgrades. However, beginning in 2002, the effects of various security regulations, specifically the enactment of the Sarbanes-Oxley Act (SOX) and the financial crisis in the U.S. becomes evident. In April 2002 when SOX was enacted, more firms actually downgraded their listing levels. In 2002, a total of 43 firms made a change to their listing level with 34 of these being downgrades. The U.S. financial crisis in the year 2007 saw the most downgrades during the entire sample period. Over 75 firms downgraded their ADR listing from levels; only 6 upgraded in the same year.

Table 4. Year of ADR listing level change

\begin{tabular}{cccccccccc}
\hline Year & \multicolumn{2}{c}{ Type of ADR } & & & & & & & \\
\hline & UP1 & UP2 & UP3 & UP4 & UP5 & UP6 & DOWN7 & DOWN8 & Total \\
\cline { 2 - 6 } $\mathbf{1 9 9 2}$ & & & & 1 & & 2 & & & 3 \\
$\mathbf{1 9 9 3}$ & & & 2 & 5 & 12 & 1 & & & 20 \\
$\mathbf{1 9 9 4}$ & & & 11 & & 21 & & 1 & & 33 \\
$\mathbf{1 9 9 5}$ & & & & 1 & 13 & & 2 & & 16 \\
$\mathbf{1 9 9 6}$ & & & 2 & 1 & 16 & & & & 19 \\
$\mathbf{1 9 9 7}$ & 1 & & & 1 & 12 & 1 & 1 & & 16 \\
$\mathbf{1 9 9 8}$ & 2 & & 2 & & 15 & & & & 19 \\
$\mathbf{1 9 9 9}$ & 3 & & 1 & 2 & 11 & & 1 & & 18 \\
$\mathbf{2 0 0 0}$ & 6 & 2 & 13 & 7 & 23 & 7 & 3 & 1 & 62 \\
$\mathbf{2 0 0 1}$ & 2 & & 16 & 1 & 25 & 2 & 5 & & 51 \\
$\mathbf{2 0 0 2}$ & & & 1 & 2 & 6 & & 23 & 11 & 43 \\
$\mathbf{2 0 0 3}$ & 1 & & 1 & & 3 & & 4 & 6 & 15 \\
$\mathbf{2 0 0 4}$ & 1 & & 4 & & 1 & & 5 & 2 & 13 \\
$\mathbf{2 0 0 5}$ & & & & 1 & & & 1 & 1 & 3 \\
$\mathbf{2 0 0 6}$ & 1 & & & & 2 & & 4 & 2 & 9
\end{tabular}




\begin{tabular}{|c|c|c|c|c|c|c|c|c|c|}
\hline 2007 & 1 & & 3 & & 2 & & 22 & 47 & 75 \\
\hline 2008 & & & & 1 & & & 5 & 3 & 9 \\
\hline 2009 & & & & & 2 & & 9 & 4 & 15 \\
\hline 2010 & & & & & & & 1 & 8 & 9 \\
\hline Total & 18 & 2 & 56 & 23 & 164 & 13 & 87 & 85 & 448 \\
\hline
\end{tabular}

$\boldsymbol{U P 1}=$ Chg from Level $4-$ Level 1. UP2 $=$ Chg from Level $4-$ Level 2. UP3 $=$ Chg from Level $4-$ Level 3. UP4 $=$ Chg from Level $1-$ Level 2. $\boldsymbol{U P 5}=$ Chg from Level $1-$ Level 3. UP6 $=$ Chg from Level $2-$ Level 3. Down $7=$ Chg from Level 2 - Level 1. Down8 = Chg from Level 3 - Level 1

Table 5 shows the distribution of firms per depositary bank. Overall, the Bank of New York establishes more ADR programs than its competitors combined $(221 ; 49.3 \%)$, followed by Citibank (118; 26.3\%), and J.P. Morgan Chase with $(78 ; 17.4 \%)$ programs in the sample.

Table 5. ADR listing level changes by depository bank

Descriptive Statistics by Depository Bank

\begin{tabular}{|c|c|c|c|c|c|c|c|c|c|c|}
\hline & \multicolumn{4}{|c|}{ Type of ADR } & \multirow[b]{2}{*}{ UP5 } & \multirow[b]{2}{*}{ UP6 } & \multirow[b]{2}{*}{ DOWN7 } & \multirow[b]{2}{*}{ DOWN8 } & \multirow[b]{2}{*}{ Total } & \multirow[b]{2}{*}{$(\%)$} \\
\hline & UP1 & UP2 & UP3 & UP4 & & & & & & \\
\hline $\mathrm{BNY}$ & 5 & & 18 & 17 & 75 & 4 & 51 & 51 & 221 & 49.3 \\
\hline CITI & 5 & 2 & 34 & 1 & 47 & 4 & 11 & 14 & 118 & 26.3 \\
\hline DB & 2 & & & & 2 & & 10 & 3 & 17 & 3.8 \\
\hline JPM & 6 & & 4 & 3 & 32 & 4 & 12 & 17 & 78 & 17.4 \\
\hline CHASE & & & & & 1 & & & & 1 & 0.2 \\
\hline BNY, CITI & & & & 1 & & & 1 & & 2 & 0.4 \\
\hline BNY, CITI, DB & & & & & 2 & & & & 2 & 0.4 \\
\hline BNY, CITI, DB, JPM & & & & & 1 & 1 & 2 & & 4 & 0.9 \\
\hline CITI, DB & & & & & 2 & & & & 2 & 0.4 \\
\hline CITI, JPM & & & & 1 & & & & & 1 & 0.2 \\
\hline CITI, DB, JPM & & & & & 2 & & & & 2 & 0.4 \\
\hline Total & 18 & 2 & 56 & 23 & 164 & 13 & 87 & 85 & 448 & 100 \\
\hline
\end{tabular}

$\boldsymbol{U P 1}=$ Chg from Level $4-$ Level 1. UP2 $=$ Chg from Level $4-$ Level 2. UP3 $=$ Chg from Level $4-$ Level 3. UP4 $=$ Chg from Level $1-$ Level 2. $\boldsymbol{U P 5}=$ Chg from Level $1-$ Level 3. UP6 $=$ Chg from Level $2-$ Level 3. Down $7=$ Chg from Level 2 - Level 1. Down8 = Chg from Level 3 - Level 1

$\mathrm{BNY}=$ Bank of New York; CITI $=$ City Bank; DB $=$ Deutsche Bank; JPM = J. P. Morgan; CHASE $=$ Chase Bank

Table 6 displays the ADR listing changes according to the ADR's home country. As shown in the table, $17.2 \%$ of the ADRs represented in the sample that underwent a change during the sample period are from the United Kingdom. $11.8 \%$ of the sampled ADRs are from Brazil, followed by $6.7 \%$ of ADRs originating from Australia and France.

Table 6. ADR listing level changes by country

Descriptive Statistics by Geographic Location

$$
\text { Type of }
$$

ADR 


$$
\begin{array}{llllllllll}
\text { UP1 } & \text { UP2 } & \text { UP3 } & \text { UP4 } & \text { UP5 } & \text { UP6 } & \text { DOWN7 } & \text { DOWN8 } & \text { Total } & (\%) \\
\hline
\end{array}
$$

\section{Panel B: Geographic Location (countries)}

\begin{tabular}{|c|c|c|c|c|c|c|c|c|c|c|c|c|}
\hline ARG & & & 10 & 3 & 11 & & & & & 3 & 27 & 6.0 \\
\hline AUS & & & & 10 & 6 & 1 & & 6 & & 7 & 30 & 6.7 \\
\hline Austria & & & & 1 & & & & & & & & \\
\hline & & & & & & & & 1 & & 1 & 3 & 0.7 \\
\hline BEL & & & & & 2 & & & 1 & & 1 & 4 & 0.9 \\
\hline BRA & 6 & & 8 & & 27 & 5 & 3 & & 4 & & 53 & 11.8 \\
\hline CHL & & & & & & & & 1 & & 1 & 2 & 0.4 \\
\hline DNK & & & & & & & & & & 1 & 1 & 0.2 \\
\hline FIN & & & 2 & & 2 & & & 1 & & 1 & 6 & 1.3 \\
\hline FRA & & & & 1 & 12 & & & 5 & & 12 & 30 & 6.7 \\
\hline GER & & & & & 5 & & & 5 & & 7 & 17 & 3.8 \\
\hline GHA & & & & & 2 & & & & & & 2 & 0.4 \\
\hline GRC & 3 & & 3 & & & & & 1 & & & 7 & 1.6 \\
\hline HKG & 2 & & & & 1 & & & 2 & & 2 & 7 & 1.6 \\
\hline HUN & 2 & & & & & & & 3 & & & 5 & 1.1 \\
\hline IND & 2 & & 9 & & & & & 1 & & 1 & 13 & 2.9 \\
\hline IRL & & & & & & & & 3 & & & 3 & 0.7 \\
\hline ISR & & & & & & & & 1 & & & 1 & 0.2 \\
\hline ITA & & & & & 5 & & & 4 & & 1 & 10 & 2.2 \\
\hline JPN & & & & & 2 & 1 & & 1 & & 4 & 8 & 1.8 \\
\hline KOR & & & 8 & & & & & 2 & & & 10 & 2.2 \\
\hline LUX & & & & & & & & 2 & & 1 & 3 & 0.7 \\
\hline MEX & & & 10 & & 11 & & & 5 & & 2 & 28 & 6.3 \\
\hline NLD & & & & & 10 & 2 & & 5 & & 6 & 23 & 5.1 \\
\hline NOR & & & & & 3 & & & 2 & & 4 & 9 & 2.0 \\
\hline NZL & & & & & 9 & & & 1 & & & 10 & 2.2 \\
\hline PHL & & & & & & & & & & 1 & 1 & 0.2 \\
\hline POL & & & & & & & & & & 1 & 1 & 0.2 \\
\hline RUS & 3 & & & & 4 & & & 1 & & 2 & 10 & 2.2 \\
\hline South Africa & & & & 3 & 2 & & & 4 & & 3 & 12 & 2.7 \\
\hline Singapore & & & & & & & & & & 1 & 1 & 0.2 \\
\hline SWE & & & & & 2 & & & 4 & & 2 & 8 & 1.8 \\
\hline SWZ & & & & & 7 & 2 & & 4 & & 1 & 14 & 3.1 \\
\hline TWN & & 2 & 2 & & & & & & & 1 & 5 & 1.1 \\
\hline UK & & & 4 & 5 & 35 & 2 & & 17 & & 14 & 77 & 17.2 \\
\hline VEN & & & & & 6 & & & 1 & & & 7 & 1.6 \\
\hline Total & 18 & 2 & 56 & 23 & 164 & 13 & 87 & & 85 & & 448 & 100 \\
\hline
\end{tabular}

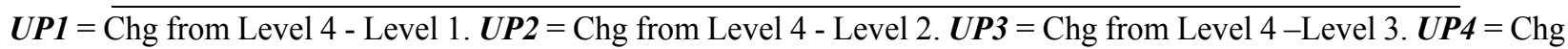
from Level $1-$ Level 2. $\boldsymbol{U P 5}=$ Chg from Level $1-$ Level 3. UP6 $=$ Chg from Level $2-$ Level 3. Down $7=$ Chg from Level 2 - Level 1. Down8 = Chg from Level 3 - Level 1 
Table 7 shows the distribution of ADR observations across industries. 12.9\% of the sample ADR firms are in the Telecommunication Services industry while 12.3\% are from Materials, and 12.1\% from Information Technology.

Table 7. ADR listing level changes by industry

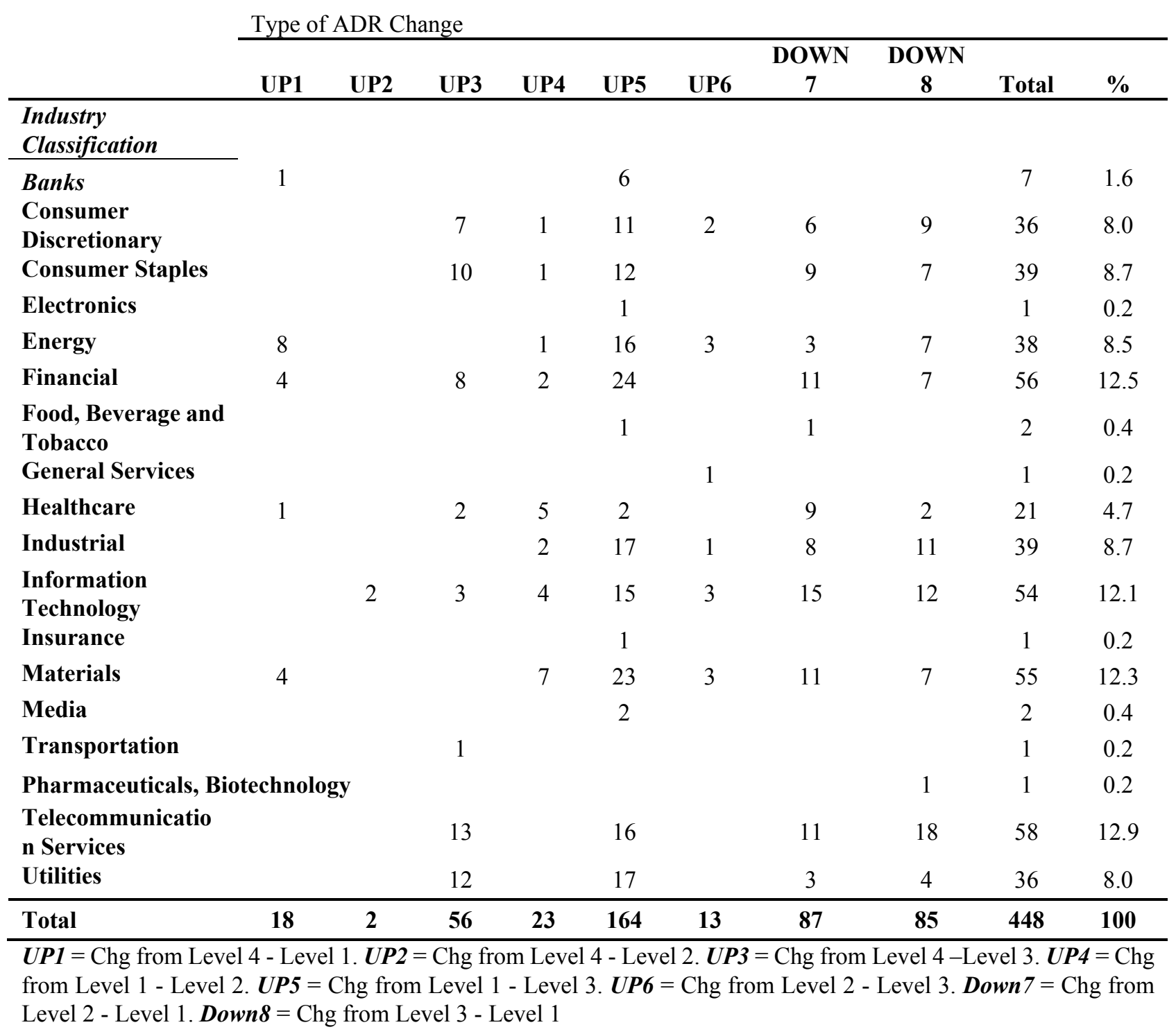

In Table 8, I group the ADRs that changed according to level of shareholder protection and legal origin. The minority shareholders' rights protection explanation for cross-listing benefits (Fuerst, 1998; LaPorta et al., 1997, 1998, 2000; Reese and Weisbach, 2002) postulates that foreign firms from weaker legal systems would experience greater improvement in their information environment upon cross-listing in the U.S. LEGAL and SHHRPROTECTION were two measures to capture the level of information disclosure of the home country.

I measure country of origin as a dummy variable for whether the foreign firm is from a country with English common law tradition (LEGAL). La Porta et al. (1997, 1998, 2000) show that the protection of minority shareholders' rights is stronger in countries with English common law tradition than in countries with civil law tradition. I measure investor protection (SHRPROTECTION) as a dummy variable for whether the foreign firm is from a country with weak investor protection or strong investor protection. 
I hypothesize that firms which originate from countries with weaker protection $($ SHRPROTECTION $=1$ ) for minority shareholders, and those coming from civil law tradition $(\mathrm{LEGAL}=0)$ experience greater visibility and lower dispersion of recommendations upon their cross-listing in the U.S.

The ADR sample consists of 448 firms from 35 countries. All major legal systems are represented -9 countries and 154 ADR firms representing $34.4 \%$ of the sample are from the English common law, 63 ADR firms (14\%) representing 8 countries are from German civil law, 24 ADR firms (5.4\%) are from Scandinavian Civil Law, and 192 ADRs (42.9\%) representing 11 countries are from French civil law.

Table 8. ADR listing changes by shareholder protection and legal origin

\begin{tabular}{|c|c|c|c|c|c|c|c|c|c|c|}
\hline Country & $\begin{array}{c}\text { Investor } \\
\text { Protection }\end{array}$ & UP1 & UP2 & UP3 & UP4 & UP5 & UP6 & DOWN7 & DOWN8 & Total \\
\hline \multicolumn{11}{|c|}{ S } \\
\hline$L A W$ & & & & & & & & & & \\
\hline COUNTRIES & BEST & & & & & & & & & \\
\hline Australia & $\mathrm{HIGH}$ & & & & 10 & 6 & 1 & 6 & 7 & 30 \\
\hline Hong Kong & $\mathrm{HIGH}$ & 2 & & & & 1 & & 2 & 2 & 7 \\
\hline United & & & & & 5 & & & & & \\
\hline Kingdom & $\mathrm{HIGH}$ & & & 4 & & 35 & 2 & 17 & 14 & 77 \\
\hline India & HIGH & 2 & & 9 & & & & 1 & 1 & 13 \\
\hline Ireland & $\mathrm{HIGH}$ & & & & & & & 3 & & 3 \\
\hline Israel & $\mathrm{HIGH}$ & & & & & & & 1 & & 1 \\
\hline New Zealand & $\mathrm{HIGH}$ & & & & & 9 & & 1 & & 10 \\
\hline Singapore & $\mathrm{HIGH}$ & & & & & & & & 1 & 1 \\
\hline South Africa & HIGH & & & & 3 & 2 & & 4 & 3 & 12 \\
\hline TOTAL & & 4 & $\mathbf{0}$ & 13 & 18 & 53 & 3 & 35 & 28 & 154 \\
\hline
\end{tabular}

FRENCH

CIVIL LAW

COUNTRIES WORST

\begin{tabular}{|c|c|c|c|c|c|c|c|c|c|}
\hline Argentina & LOW & & 10 & 3 & 11 & & & 3 & 27 \\
\hline Belgium & LOW & & & & 2 & & 1 & 1 & 4 \\
\hline Brazil & LOW & 6 & 8 & & 27 & 5 & 3 & 4 & 53 \\
\hline Chile & LOW & & & & & & 1 & 1 & 2 \\
\hline France & LOW & & & 1 & 12 & & 5 & 12 & 30 \\
\hline Greece & LOW & 3 & 3 & & & & 1 & & 7 \\
\hline Italy & LOW & & & & 5 & & 4 & 1 & 10 \\
\hline Mexico & LOW & & 10 & & 11 & & 5 & 2 & 28 \\
\hline Netherlands & LOW & & & & 10 & 2 & 5 & 6 & 23 \\
\hline Philippines & LOW & & & & & & & 1 & 1 \\
\hline Venezuela & LOW & & & & 6 & & 1 & & 7 \\
\hline TOTAL & & 9 & 31 & 4 & 84 & 7 & 26 & 31 & 192 \\
\hline
\end{tabular}

\section{GERMAN}

CIVIL LAW COUNTRIES

\begin{tabular}{|c|c|c|c|c|}
\hline Austria & LOW & & 1 & 1 \\
\hline Germany & LOW & 5 & 5 & 7 \\
\hline
\end{tabular}




\begin{tabular}{|c|c|c|c|c|c|c|c|c|c|c|}
\hline Hungary & LOW & 2 & & & & & & 3 & & 5 \\
\hline Japan & HIGH & & & & & 2 & 1 & 1 & 4 & 8 \\
\hline Korea & LOW & & & 8 & & & & 2 & & 10 \\
\hline Poland & HIGH & & & & & & & & 1 & 1 \\
\hline Switzerland & LOW & & & & & 7 & 2 & 4 & 1 & 14 \\
\hline Taiwan & HIGH & & 2 & 2 & & & & & 1 & 5 \\
\hline TOTAL & & 2 & 2 & 10 & 1 & 14 & 3 & 16 & 15 & 63 \\
\hline
\end{tabular}

\section{SCANDINAVIAN CIVIL LAW COUNTRIES}

\begin{tabular}{|c|c|c|c|c|c|c|c|c|c|c|}
\hline Denmark & LOW & & & & & & & & 1 & 1 \\
\hline Finland & LOW & & & 2 & & 2 & & 1 & 1 & 6 \\
\hline Norway & HIGH & & & & & 3 & & 2 & 4 & 9 \\
\hline Sweden & HIGH & & & & & 2 & & 4 & 2 & 8 \\
\hline TOTAL & & $\mathbf{0}$ & 0 & 2 & 0 & 7 & 0 & 7 & 8 & 24 \\
\hline
\end{tabular}

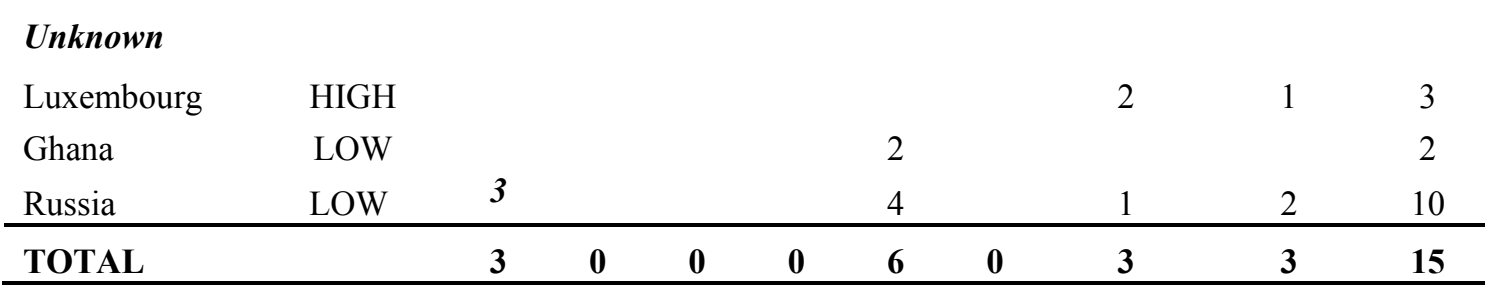

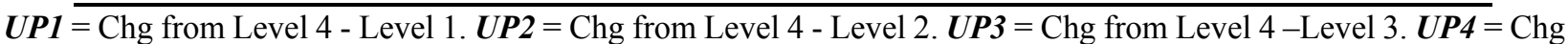
from Level 1 - Level 2. UP5 $=$ Chg from Level $1-$ Level 3. UP6 $=$ Chg from Level $2-$ Level 3. Down $7=$ Chg from Level 2 - Level 1. Down8 = Chg from Level 3 - Level 1

\subsection{Descriptive Statistics}

\subsubsection{Pre-Change}

Table 9 Panel A shows the descriptive statistics pre-change according to the direction of change for all the variables used in the models. For the variable SIZE as measured by total assets, UP6 was 50893, followed by UP5 (39740), and UP4 (33750). UP3 had the lowest MEAN SIZE (4098) and the lowest MVE (2885.6) but the highest LEV (1.5275). UP4 had the lowest LEV (0.3422). UP5 had the highest MVE (18601) followed by UP6 (12205). Before the ADRs changed their listing level, DOWN7 experienced more Analysts' following (14.66), followed by UP5 (10.31) and UP6 (10.28). Before the ADRs changed their listing levels, analyst forecast was more accurate for ADR firms in UP4, and UP6. UP2 firms saw more forecast error prior to the change.

In terms of forecast dispersion, UP3 (.3739) and UP2 (.3491) saw more dispersion in the accuracy of their forecast. DOWN7 (.1693) followed by DOWN8 (.1764) saw the least amount of dispersion in the accuracy of their forecast.

Table 9. Descriptive statistics of variables by ADR listing level pre and post change

\section{Panel A}

Descriptive Statistics of Variables - Pre Change

\begin{tabular}{|c|c|c|c|c|c|c|c|c|}
\hline Variables & UP1 & UP2 & UP3 & UP4 & UP5 & UP6 & DOWN7 & DOWN8 \\
\hline SIZE & 5403 & 5586 & 4098 & 33750 & 39740 & 50893 & 32200 & 29286 \\
\hline$L E V$ & 1.594 & 0.8976 & 1.5275 & 0.3422 & 0.6179 & 0.6802 & 0.6144 & 0.6215 \\
\hline
\end{tabular}




\begin{tabular}{lcccccccc} 
MVE & 3186 & 3372 & 2885.6 & 4320 & 18601 & 12205 & 7668 & 9695 \\
NUM & 6.21 & 6.18 & 9.2 & 9.47 & 10.31 & 10.28 & 14.66 & 7.52 \\
FERROR & 0.4436 & 0.7961 & 0.4522 & 0.1772 & 0.2267 & 0.1685 & 0.226 & 0.1735 \\
FORDISP & 0.312 & 0.3491 & 0.3739 & 0.3397 & 0.2782 & 0.329 & 0.1693 & 0.1764 \\
\hline
\end{tabular}

\section{Panel B}

Descriptive Statistics of Variables - Post Change

\begin{tabular}{|c|c|c|c|c|c|c|c|c|}
\hline & $\begin{array}{l}\text { Type of } \\
\text { Change } \\
\end{array}$ & & & & & & & \\
\hline Variables & UP1 & UP2 & UP3 & UP4 & UP5 & UP6 & DOWN7 & DOWN8 \\
\hline SIZE & 5810 & 5835 & 6021 & 45102 & 41623 & 51746 & 31152 & 29140 \\
\hline$L E V$ & 1.583 & 0.8961 & 2.18 & 0.9007 & 0.6314 & 0.6093 & 0.6308 & 0.8315 \\
\hline$M V E$ & 3257 & 3591 & 11077 & 4465 & 36593 & 35500 & 11615 & 10531 \\
\hline$N U M$ & 6.53 & 6.33 & 6.56 & 8.01 & 7.85 & 6.91 & 7.41 & 7.29 \\
\hline FERROR & 0.3581 & 0.4168 & 0.2015 & 0.1208 & 0.21 & 0.1468 & 0.3751 & 0.1945 \\
\hline FORDISP & 0.2414 & 0.2734 & 0.3235 & 0.2734 & 0.3051 & 0.1544 & 0.2617 & 0.4301 \\
\hline
\end{tabular}

FERROR is measured as the absolute value of actual analyst forecast minus the mean analyst forecast standardized by the actual analyst forecast. ForDisp Forecast dispersion measured as the standard deviation of analyst forecast standardized by the absolute value of the mean analyst forecast. $N U M$ is defined as the number of $\mathrm{I} / \mathrm{B} / \mathrm{E} / \mathrm{S}$ analysts that report forecast estimates for each firm. Size is measured as the firm's total assets. Lev is measured as total assets/total liabilities. MVE is measured as the natural log of the ADR's market value of equity.

$\boldsymbol{U P 1}=$ Chg from Level $4-$ Level 1. $\boldsymbol{U P 2}=\mathrm{Chg}$ from Level $4-$ Level 2. $\boldsymbol{U P 3}=\mathrm{Chg}$ from Level $4-$ Level 3. $\boldsymbol{U P 4}=\mathrm{Chg}$ from Level $1-$ Level 2. $\boldsymbol{U P 5}=$ Chg from Level $1-$ Level 3. UP6 $=$ Chg from Level $2-$ Level 3. Down $7=$ Chg from Level 2 - Level 1. Down = Chg from Level 3 - Level 1

\subsubsection{Descriptive Statistics - Post-Change}

Table 9 Panel B shows the descriptive statistics post-change according to the direction of change for all the variables used in the models. For the variable SIZE, UP6 had the largest set of ADR firms as measured by total assets with 51746 in assets, followed by UP4 (45102), and UP5 (41623). UP1 was smaller in size with (5810) in assets. UP3 had the highest LEV (2.18). UP6 had the lowest $L E V(0.6093)$ followed by DOWN7 (.6308) and UP5 (0.6314). Once again, as in the pre-change table, UP5 had the highest MVE (36593) followed by UP6 (35500).

During the post change era, the number of analyst following decreased for all ADR subsamples although in that same period except for UP1 and UP2. After the ADRs changed their listing level, UP1 had more Analysts' following (6.53), followed by UP2 (6.33).

Forecast Accuracy also improved in the post-change period for all ADR samples. In terms of forecast dispersion, DOWN8 (.4301) and UP3 (.3235) saw more dispersion in the accuracy of their forecast. UP6 (.1544) followed by $D O W N 7$ (.2617) saw the least amount of dispersion in the accuracy of their forecast. Compared to the pre-change period, forecast dispersion improved (decreased) for UP1, UP2, UP3, UP4, and UP6.

\subsubsection{Correlation Matrix}

Table 10 provides the correlations between the variables used in the regression models. The negative significant correlation between FERROR and NUM and between FORDISP and NUM suggests a decrease in forecast error and forecast dispersion when the number of analyst following increase. The negative significant correlation between FERROR and SHRPROTECTION suggests less forecast error when the ADRs come from countries with weak shareholder protection. The positive significant correlation between NUM and LEGAL is consistent with the bonding hypothesis. This correlation suggests that ADRs from civil law countries are more likely to list as a level II or Level III which in effect would increase the number of analysts following the firm. 
Table 10. Correlation matrix

\begin{tabular}{lrrrrrrrr} 
Variable & FERROR & FORDISP & NUM & SIZE & LEV & MVE & LEGAL & SHRPROTECTION \\
\hline FERROR & 1 & $0.341^{* *}$ & $-0.056^{* *}$ & 0.009 & -0.023 & 0.006 & 0.003 & $-0.020^{* *}$ \\
FORDISP & $0.341^{* *}$ & 1 & $-0.109^{* *}$ & 0.002 & 0.001 & 0.003 & 0.001 & -0.001 \\
NUM & $-0.056^{* *}$ & $-0.109^{* *}$ & 1 & -0.009 & -0.013 & $-0.018^{*}$ & $.054^{* *}$ & -0.003 \\
Size & 0.009 & 0.002 & -0.009 & 1 & 0.00 & -0.003 & -0.012 & -0.005 \\
LEV & -0.023 & 0.001 & -0.013 & 0.00 & 1 & 0.001 & $-0.017^{* *}$ & $-0.031^{* *}$ \\
MVE & 0.006 & 0.003 & $-0.018^{*}$ & -0.003 & 0.001 & 1 & $.124^{* *}$ & $-0.027^{* *}$ \\
LEGAL & 0.003 & 0.001 & $.054^{* *}$ & -0.012 & $-0.017^{* *}$ & $.124^{* *}$ & 1 & $-0.213^{* *}$ \\
SHRPROTECTION & $-0.020^{* *}$ & -0.001 & -0.003 & -0.005 & $-0.031^{* *}$ & $-0.027^{* *}$ & $-0.213^{* *}$ & 1 \\
\hline
\end{tabular}

FERROR is measured as the absolute value of actual analyst forecast minus the mean analyst forecast standardized by the actual analyst forecast. ForDisp Forecast dispersion measured as the standard deviation of analyst forecast standardized by the absolute value of the mean analyst forecast. $N U M$ is defined as the number of $\mathrm{I} / \mathrm{B} / \mathrm{E} / \mathrm{S}$ analysts that report forecast estimates for each firm. Size is measured as the firm's total assets. Lev is measured as total assets/total liabilities. MVE is measured as the natural log of the ADR's market value of equity.

*Correlation is significant at the $10 \%$ level

$* *$ Correlation is significant at the $5 \%$ level

$* * *$ Correlation is significant at the $1 \%$ level

\subsubsection{Descriptive Statistics - Univariate Analysis}

Paired t-test results on the full sample for the upgrade and downgrade sample is presented in table 11. In Panel A of table 11, I present univariate analysis results for the upgrade and downgrade sample. The results suggest that those ADRs that downgrade their ADR listing have greater forecast error and forecast dispersion compared with those ADRs that upgrade. The difference in the upgrade and downgrade sample with respect to the mean difference in forecast error and forecast dispersion sample is significant at the 5\% and $10 \%$ level respectively. The paired t-test analysis also suggests that those ADRs that upgrade their ADR listing have greater number of analyst following the firm. Thus, there is a significant difference in the upgrade and downgrade sample with respect to the mean difference in the number of analyst following. This result is significant at the $1 \%$ level. Additionally, ADRs that upgrade their listing level are greater in size measured by their total assets, and have a higher market value compared with those ADRs that downgrade. These results are significant at the $1 \%$ level.

In Panel B of table 11, I present univariate analysis results for the upgrade and full sample. Panel B shows that ADR firms that upgraded their listing level have less forecast error, and more analysts' following than those ADRs that did not change. These results are significant at the $1 \%$ level. Those firms that upgrade are also highly leveraged compared to the full sample.

In Panel $\mathrm{C}$ of table 11, I present univariate analysis results for the downgrade and full sample. Panel $\mathrm{C}$ shows that ADR firms that downgraded their listing level have more forecast error than those ADRs that did not change. Also, ADR firms that downgraded their listing level have more analysts' following than those ADRs that did not change. This is probably due to those firms that downgraded from a Level III to Level II or a Level III to Level I. Due to their prior listing level, some residual effect still exists. Also downgrading from a Level III to Level II would still allow the ADR to benefit from more analysts' following. These results are significant at the $1 \%$ level.

Table 11. Paired t-Test results for upgrade, downgrade, and full sample

Panel A

\begin{tabular}{lcccccc}
\hline \multicolumn{2}{c}{$\begin{array}{c}\text { Upgrades } \\
\text { (firms) }\end{array}$} & \multicolumn{2}{c}{$\begin{array}{c}\text { Downgrades } \\
\text { (firms) }\end{array}$} \\
\hline & Mean & Std & Mean & Std & Diff in Means & t-value \\
\hline Test Variables: & & & & & & \\
FERROR & 8.134 & 7.073 & 9.6793 & 54.978 & -1.5453 & $-0.027(0.978)$ \\
FORDISP & 0.3027 & 1.1303 & 0.1713 & 0.34686 & 0.1314 & $3.568(.000)^{* * *}$
\end{tabular}




$\begin{array}{lllllll}N U M & 10.07 & 8.053 & 12.4533 & 9.4115 & -2.3833 & -6.336(.000)^{* * *}\end{array}$

\section{Control variables:}

\begin{tabular}{lcccccc} 
Size & 33053.245 & 87948 & 30801.047 & 107461 & 2252.1983 & $-.027(.978)$ \\
LEV & 0.7994 & 4.35 & 0.6178 & 0.25246 & 0.1816 & $.770(.442)$ \\
MVE & 13584.87 & 29768 & 8681.359 & 12312.988 & 4903.511 & $3.077(.002)^{* * *}$ \\
\hline
\end{tabular}

Panel B

\begin{tabular}{lcccccc}
\hline \multicolumn{2}{c}{$\begin{array}{c}\text { Upgrades } \\
\text { (firms) }\end{array}$} & \multicolumn{2}{c}{$\begin{array}{c}\text { Full Sample } \\
\text { (firms) }\end{array}$} \\
\hline & Mean & Std & Mean & Std & Diff in Means & t-value \\
\hline Test Variables: & & & & & & \\
FERROR & 8.134 & 7.073 & 34.12 & 35.601 & -25.986 & $-4.497(.000)^{* * *}$ \\
FORDISP & 0.3027 & 1.1303 & 0.0299 & 20.098 & 0.2728 & $1.271(.205)$ \\
NUM & 10.07 & 8.053 & 4.7813 & 7.589 & 5.2887 & $2.926(.000)^{* * *}$
\end{tabular}

\section{Control variables:}

\begin{tabular}{|c|c|c|c|c|c|c|}
\hline Size & 33053.245 & 87948 & 63939.156 & 18092 & -30885.911 & $-3.069(.002)^{* *}$ \\
\hline$L E V$ & 0.7994 & 4.35 & 0.5764 & 3.19 & 0.223 & $.818(.414)$ \\
\hline$M V E$ & 13584.87 & 29768 & 23328 & 81813 & -9743.13 & $-9.302(.000) * * *$ \\
\hline \multicolumn{7}{|l|}{ Panel C } \\
\hline & \multicolumn{2}{|c|}{$\begin{array}{c}\text { Downgrades } \\
\text { (firms) }\end{array}$} & \multicolumn{2}{|c|}{$\begin{array}{c}\begin{array}{c}\text { Full Sample } \\
\text { (firms) }\end{array} \\
\end{array}$} & & \\
\hline & Mean & Std & Mean & Std & Diff in Means & t-value \\
\hline \multicolumn{7}{|c|}{ Test Variables: } \\
\hline FERROR & 9.6793 & 54.978 & 34.12 & 35.601 & -24.4407 & $10.732(.000)^{* * *}$ \\
\hline FORDISP & 0.1713 & 0.34686 & 0.0299 & 20.098 & 0.1414 & $-.565(.573)$ \\
\hline$N U M$ & 12.4533 & 9.4115 & 4.7813 & 7.589 & 7.672 & $3.921(.000)^{* * *}$ \\
\hline \multicolumn{7}{|c|}{ Control variables: } \\
\hline Size & 30801.047 & 107461 & 63939.156 & 18092 & -33138.109 & $-4.770(.000)^{* * *}$ \\
\hline$L E V$ & 0.6178 & 0.25246 & 0.5764 & 3.19 & 0.0414 & $4.604(.000) * * *$ \\
\hline$M V E$ & 8681.359 & 12312.988 & 23328 & 81813 & -14646.641 & $-11.444(.000)^{* * *}$ \\
\hline
\end{tabular}

FERROR is measured as the absolute value of actual analyst forecast minus the mean analyst forecast standardized by the actual analyst forecast. ForDisp Forecast dispersion measured as the standard deviation of analyst forecast standardized by the absolute value of the mean analyst forecast. $N U M$ is defined as the number of $\mathrm{I} / \mathrm{B} / \mathrm{E} / \mathrm{S}$ analysts that report forecast estimates for each firm. Size is measured as the firm's total assets. Lev is measured as total assets/total liabilities. MVE is measured as the natural log of the ADR's market value of equity.

* Significant at the $10 \%$ level

** Significant at the $5 \%$ level

*** Significant at the $1 \%$ level

\subsection{Multivariate Regression Analysis -Forecast Accuracy - Full Sample}

For each ADR type, I regress the change in forecast error on a set of independent control variables. The dependent variable is the change in forecast error. I apply the regression specification to the following four models: (1) Model 1, $\mathrm{UP}=1$ for ADRs that upgrade and 0 - otherwise; DOWN $=1$ - for ADRs that downgraded and 0 - otherwise; (2) Model $2, \mathrm{UP}=1$ for ADRs that upgrade to Level 3, and 0 otherwise.; DOWN $=1$ for ADRs that downgraded and 0 otherwise; (3) Model 3, UP = 1 for ADRs that upgrade to Level 3, and 0 otherwise.; DOWN $=1$ for ADRs that downgraded and 0 otherwise; (4) Model 4, UP = 1 for ADRs that upgrade to Level 2 or Level 3, and 0 otherwise.; DOWN $=1$ for ADRs that downgraded and 0 otherwise. By separating the upgrade sample, downgrade sample, and Level I, II, and III sample, I can gauge the importance of the listing levels effect on the information environment of ADRs. This listing effect may exist due to the fact that listing on an exchange subjects the ADRs to the SEC's stringent disclosure regulations. 
The results on the full sample (Model 1) reported in table 12show that ADRs that upgrade their listing level experience increased forecast accuracy. This result is negatively significant at the $1 \%$ level in Model 1, Model 2, Model4, and negatively significant at the $10 \%$ level in Model 3 . The significant positive correlation on the downgrade sample suggests that ADRs that downgrade are associated with less forecast accuracy. These results are positively significant at the 1\% level in Model 2, Model 3, Model4, and positively significant at the $10 \%$ level in Model 1.

As predicted, the number of analyst following appears to be a significant variable in the information environment of ADR firms. According to table 12, the results of the full sample in (Model 1 and Model 4) show that the number of recommendations is negatively and significantly associated with the dispersion of analysts' forecast.

Table 12. Multivariate Regression Analysis- forecast accuracy

Full Sample

\begin{tabular}{|c|c|c|c|c|}
\hline \multirow[b]{2}{*}{ Variables } & \multirow{2}{*}{\multicolumn{2}{|c|}{ Model (2) }} & \multirow{2}{*}{ Model (3) } & \multirow{2}{*}{ Model (4) } \\
\hline & & & & \\
\hline \multirow[t]{2}{*}{ Intercept } & 8.14 & 0.934 & -10.245 & -0.473 \\
\hline & $(9.908)^{* * *}$ & -0.01 & $(-1.827)^{* *}$ & $(-1.118)$ \\
\hline \multirow[t]{2}{*}{$U P$} & -0.107 & -0.288 & -0.132 & -0.057 \\
\hline & $(-7.379) * * *$ & $(-16.277)^{* * *}$ & $(-2.528)^{*}$ & $(-3.808)^{* * *}$ \\
\hline \multirow[t]{2}{*}{$D O W N$} & 0.025 & 0.033 & 0.288 & 0.017 \\
\hline & $(1.878)^{*}$ & $(2.60)^{* * *}$ & $(6.273)^{* * *}$ & $(1.266)^{* *}$ \\
\hline \multirow[t]{2}{*}{ Level I } & - & - & -0.135 & -0.057 \\
\hline & & & $(-1.811)^{*}$ & $(-3.965)^{* * *}$ \\
\hline \multirow[t]{2}{*}{ Level II } & _- & - & 0.255 & 0.126 \\
\hline & & - & $(2.125)^{* *}$ & $(3.808)^{* * *}$ \\
\hline \multirow{2}{*}{ Level III } & _- & _- & -0.206 & -0.14 \\
\hline & - & - & $(-1.772)^{*}$ & $(-9.787)^{* * *}$ \\
\hline \multirow[t]{2}{*}{ SIZE } & -0.004 & 0 & 0.001 & 0.004 \\
\hline & $(-.318)$ & -0.009 & -0.083 & -0.335 \\
\hline \multirow[t]{2}{*}{$L E V$} & -0.019 & 0.005 & 0.004 & -0.02 \\
\hline & $(-1.470)$ & -0.367 & -0.292 & $(-1.534)$ \\
\hline \multirow[t]{2}{*}{$M V E$} & 0.011 & 0.013 & 0.003 & 0.012 \\
\hline & -0.861 & -1.008 & -0.188 & -0.884 \\
\hline \multirow[t]{2}{*}{$N U M$} & 0.025 & 0.016 & 0.012 & 0.12 \\
\hline & $(1.845)^{*}$ & -1.237 & -0.936 & $(8.841)^{* * *}$ \\
\hline \multirow[t]{2}{*}{$L E G A L$} & -0.122 & -0.009 & -0.674 & -0.478 \\
\hline & $(-8.147)^{* * *}$ & -0.558 & $(-7.065)^{* * *}$ & $(-16.988)^{* * *}$ \\
\hline \multirow[t]{2}{*}{ SHRPROTECTION } & -0.344 & -0.344 & -0.46 & -0.326 \\
\hline & $(-16.972)^{* * *}$ & $(-16.979)^{* * *}$ & $(-7.065) * * *$ & $(-17.663)^{* * *}$ \\
\hline$N$ & 2093 & 2093 & 2093 & 2093 \\
\hline Adj. $R^{2}$ & 0.014 & 0.061 & 0.062 & 0.099 \\
\hline
\end{tabular}

The table contains regression results for the ADR control sample. Forecast error is measured as the absolute value of actual analyst forecast minus the mean analyst forecast standardized by the actual analyst forecast. In Model $1, U P=$ 1 for ADRs that upgrade and 0 - otherwise; $D O W N=1$ - for ADRs that downgraded and 0 - otherwise. In Model 2, $U P=1$ for ADRs that upgrade to Level 3, and 0 otherwise. $D O W N=1$ for ADRs that downgraded and 0 otherwise. In Model 3, $U P=1$ for ADRs that upgrade to Level 3, and 0 otherwise. $D O W N=1$ for ADRs that downgraded and 0 otherwise. In Model 4, $U P=1$ for ADRs that upgrade to Level 2 or Level 3, and 0 otherwise.; $D O W N=1$ for ADRs that downgraded and 0 otherwise. Level $1=1$ - ADRs listed on level 1 and 0 - otherwise. Level $2=1$ - ADRs listed on level 2 and 0 - otherwise. Level $3=1$ - ADRs listed on level 3 and 0 - otherwise. Size is measured as the firm's total assets. Lev is measured as total assets/total liabilities. MVE is measured as the natural log of the ADR's market value of equity. $N U M$ is defined as the number of $\mathrm{I} / \mathrm{B} / \mathrm{E} / \mathrm{S}$ analysts that report forecast estimates for each ADR firm. 
ForDisp Forecast dispersion measured as the standard deviation of analyst forecast standardized by the absolute value of the mean analyst forecast. Legal is a dummy variable that takes the value of 1 if the ADR's home country practices common law and 0 if civil law. Legal variables are from La Porta et al. [1998]. SHRPROTECTION is a dummy variable that takes the value of 1 if the ADR's home country has weak shareholder protection and 0 if strong shareholder protection. The t-value is reported in parentheses. $* * * * *$, and $*$ denote significance at 1,5 , and $10 \%$, respectively.

A comparison of Models 3 and 4 captures the significant role of the ADR listing effect on the information environment of ADRs when they cross-list regardless if they changed or not. The coefficient of the variable Level I and Level III is comparable in direction (negative) and statistical significance (1\%) in Models 3 and 4. This suggests that ADRs that cross-list into the U.S. market experience increased forecast accuracy. Level II however showed a positive significant association with forecast error.

\subsubsection{Multivariate Regression Analysis -Number of Analyst Following - Full Sample}

In table 13, I regress the change in the number of analysts following on a set of independent control variables. The dependent variable is the change in number of analyst following. I apply the regression specification to the following four models: (1) Model 1, UP = 1 for ADRs that upgrade and 0 -otherwise; DOWN $=1$ - for ADRs that downgraded and 0 - otherwise; (2) Model 2, UP $=1$ for ADRs that upgrade to Level 3, and 0 otherwise.; DOWN $=1$ for ADRs that downgraded and 0 otherwise; (3) Model 3, UP = 1 for ADRs that upgrade to Level 3, and 0 otherwise.; DOWN = 1 for ADRs that downgraded and 0 otherwise; (4) Model 4, UP $=1$ for ADRs that upgrade to Level 2 or Level 3, and 0 otherwise.; DOWN $=1$ for ADRs that downgraded and 0 otherwise.

Table 13. Multivariate Regression Analysis - Number of analyst following

Full Sample

\begin{tabular}{|c|c|c|c|c|}
\hline \multirow{2}{*}{ Variables } & Model (1) & Model (2) & Model (3) & Model (4) \\
\hline & & & & \\
\hline \multirow[t]{2}{*}{ Intercept } & 1.368 & 1.367 & 2.313 & 1.578 \\
\hline & $(7.019)^{* *}$ & $(7.016) * * *$ & $(1.783)^{* *}$ & $(9.290)^{* * *}$ \\
\hline \multirow[t]{2}{*}{$U P$} & 0.097 & -0.009 & 0.1 & 0.005 \\
\hline & $(5.616)^{* * *}$ & $(-.693)$ & $(1.890)^{*}$ & -0.411 \\
\hline \multirow[t]{2}{*}{$D O W N$} & -0.015 & -0.087 & -0.097 & -0.097 \\
\hline & $(-1.177)$ & $(-6.195) * * *$ & $(-5.635) * * *$ & $(5.634)^{* * *}$ \\
\hline \multirow[t]{2}{*}{ Level I } & - & _ & -0.057 & -0.193 \\
\hline & & & $(-.720)$ & $(-14.224) * * *$ \\
\hline \multirow[t]{2}{*}{ Level II } & - & - & 0.3 & 0.093 \\
\hline & & & $(2.507)^{* *}$ & $(6.354)^{* * *}$ \\
\hline \multirow[t]{2}{*}{ Level III } & - & - & 0.2 & 0.266 \\
\hline & & & $(1.730)^{*}$ & $(14.630)^{* * *}$ \\
\hline \multirow[t]{2}{*}{ SIZE } & -0.012 & -0.01 & -0.01 & -0.01 \\
\hline & $(-.960)$ & $(-.786)$ & $(-.767)$ & $(-.768)$ \\
\hline \multirow[t]{2}{*}{$L E V$} & -0.015 & -0.016 & -0.015 & -0.015 \\
\hline & $(-1.206)$ & $(-1.247)$ & $(-1.205)$ & $(-1.224)$ \\
\hline \multirow[t]{2}{*}{$M V E$} & -0.006 & -0.027 & -0.028 & -0.028 \\
\hline & $(-.500)$ & $(-2.047)^{* *}$ & $(-2.118)^{* *}$ & $(-2.117)^{* *}$ \\
\hline$N U M$ & $* * *$ & $* * *$ & $* * *$ & $* * *$ \\
\hline \multirow[t]{2}{*}{$L E G A L$} & 0.272 & 0.307 & 0.004 & 0.22 \\
\hline & $(17.510)^{* * *}$ & $(18.585)^{* * *}$ & -0.044 & $(14.630)^{* * *}$ \\
\hline \multirow[t]{2}{*}{ SHRPROTECTION } & -0.043 & 0.043 & -0.003 & -0.112 \\
\hline & $(-2.206)^{* *}$ & -2.208 & $(-.044)$ & $(-6.278) * * *$ \\
\hline$N$ & 2093 & 2093 & 2093 & 2093 \\
\hline Adj. $R^{2}$ & 0.055 & 0.0583 & 0.061 & 0.0614 \\
\hline
\end{tabular}

$\Delta N U M_{t}=B_{0}+B_{1} \mathrm{UP}_{\mathrm{it}}+B_{2}$ DOWN $_{\mathrm{it}}+B_{3}$ LEVEL1 $_{\mathrm{it}}+B_{4}$ LEVEL $_{\mathrm{it}}+B_{5} \mathrm{LEVEL}_{\mathrm{it}}+B 6$ SIZE $++B_{7} I N D+B_{8} M V E_{t}+$ $B_{9} \mathrm{LEV}_{\mathrm{it}}+B_{10} \mathrm{LEGAL}_{\mathrm{it}}+B_{11} \mathrm{SHRPROTECTION}_{\mathrm{it}}$ 
The table contains regression results for the ADR control sample. $N U M$ is defined as the number of $\mathrm{I} / \mathrm{B} / \mathrm{E} / \mathrm{S}$ analysts that report forecast estimates for each ADR firm. In Model 1, $U P=1$ for ADRs that upgrade and 0 -otherwise; $D O W N$ $=1-$ for ADRs that downgraded and 0 -otherwise. In Model 2, UP = 1for ADRs that upgrade to Level 3, and 0 otherwise; $D O W N=1$ for ADRs that downgraded and 0 otherwise. In Model 3, $U P=1$ for ADRs that upgrade to Level 3 , and 0 otherwise; $D O W N=1$ for ADRs that downgraded and 0 otherwise. In Model 4, $U P=1$ for ADRs that upgrade to Level 2 or Level 3, and 0 otherwise.; $D O W N=1$ for ADRs that downgraded and 0 otherwise. Level $1=1$ - ADRs listed on level 1 and 0 -otherwise. Level $2=1$ - ADRs listed on level 2 and 0 -otherwise. Level $3=1$ - ADRs listed on level 3 and 0 - otherwise. Size is measured as the firm's total assets. Lev is measured as total assets/total liabilities. MVE is measured as the natural log of the ADR's market value of equity. Legal is a dummy variable that takes the value of 1 if the ADR's home country practices common law and 0 if civil law. Legal variables are from La Porta et al. [1998]. SHRPROTECTION is a dummy variable that takes the value of 1 if the ADR's home country has weak shareholder protection and 0 if strong shareholder protection. The $t$-value is reported in parentheses. ${ }^{* *}, * *$, and * denote significance at 1,5 , and $10 \%$, respectively.

In Models 1 and 3, ADRs that upgrade their listing level have a positively significant association with the number of analysts following the firm. For Models 1 and 3, the results were significant at the $1 \%$ and $10 \%$ level respectively. These results demonstrate that ADRs that are exchange listed (upgraded) benefit with additional analysts' coverage compared with those that are not. For those ADRs that downgraded their listing level, the results are negatively significant at the $1 \%$ level for Models 2, 3, and 4. This suggests that ADRs that downgrade their listing level have less analysts covering their firm.

Models 3 and 4 include ADRs that changed (upgrade or downgrade) and it also includes ADRs that did not changed and are listed on Level I, II, or III. Model 3 showed positive significant coefficients for Level II, and III (5\% and 10\% respectively). Model 4 showed positive significant coefficients for Level I, II, and III at the $1 \%$ level.

\subsubsection{Multivariate Regression Analysis -Forecast Dispersion - Full Sample}

I also analyzed the benefits of ADR changing their listing level by examining changes in the dispersion of analyst forecast. Forecast dispersion also served as a proxy for the information environment of a firm (Diether et al., 2002; Park, 2005; Boheme et al., 2006). Accordingly, as the information environment of a firm improves, analysts forecast of the firm would converge. Thus, I hypothesize that the dispersion of recommendations should be lower for firms that upgraded their listing level. I measure forecast dispersion as the standard deviation of forecasts divided by the mean forecast. I compute the average of the forecast dispersion across firms in each listing category.

In table 14, I separately run four regression models with different samples: (1) Model 1, UP $=1$ for ADRs that upgrade and 0 - otherwise; DOWN $=1$ - for ADRs that downgraded and 0 - otherwise; (2) Model 2, UP $=1$ for ADRs that upgrade to Level 3, and 0 otherwise.; DOWN = 1for ADRs that downgraded and 0 otherwise; (3) Model 3, UP = 1 for ADRs that upgrade to Level 3, and 0 otherwise.; DOWN $=1$ for ADRs that downgraded and 0 otherwise; (4) Model 4, UP $=1$ for ADRs that upgrade to Level 2 or Level 3, and 0 otherwise.; DOWN $=1$ for ADRs that downgraded and 0 otherwise. The dependent variable is forecast dispersion.

Table 14. Multivariate Regression Analysis - Forecast dispersion

Full Sample

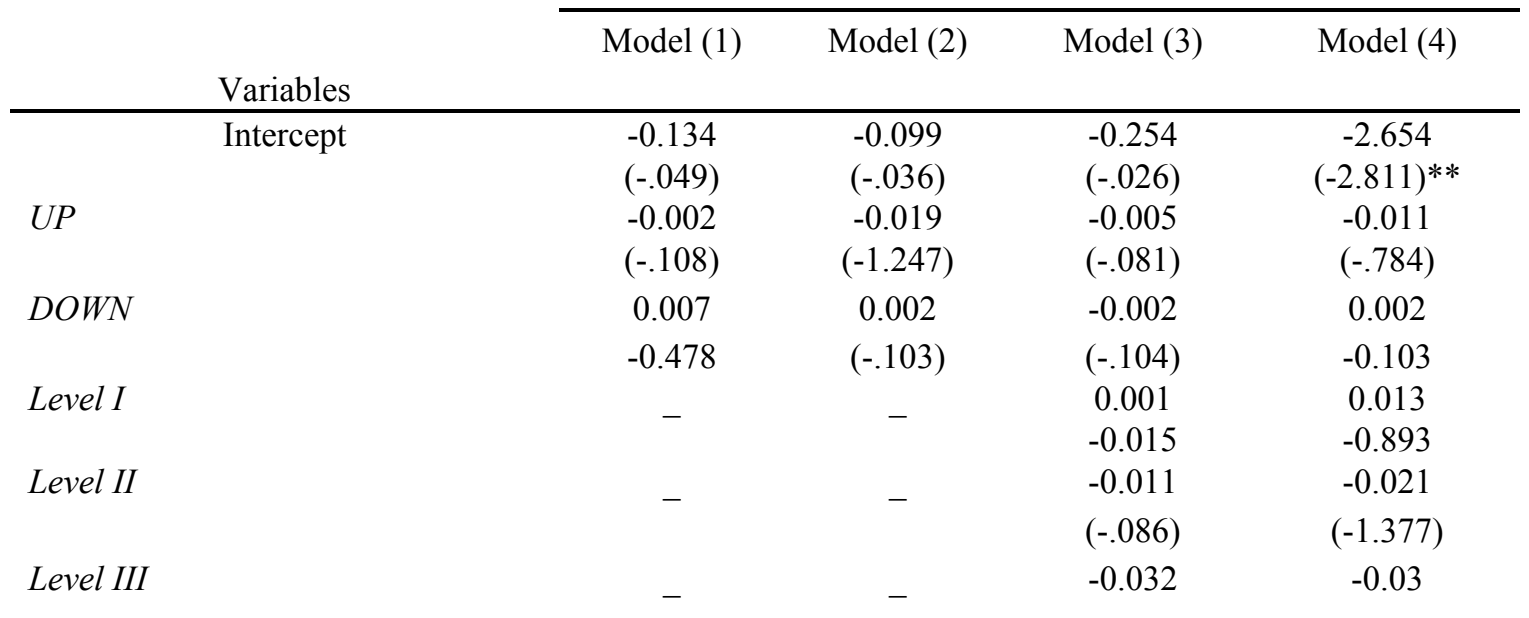




\begin{tabular}{|c|c|c|c|c|}
\hline & & & $(-.250)$ & $(-.760)$ \\
\hline \multirow[t]{2}{*}{ SIZE } & 0.003 & 0.003 & 0.003 & 0.003 \\
\hline & -0.208 & -0.222 & -0.252 & -0.252 \\
\hline \multirow[t]{2}{*}{$L E V$} & 0.002 & 0.001 & 0.002 & 0.002 \\
\hline & -0.158 & -0.097 & -0.167 & -0.153 \\
\hline \multirow[t]{2}{*}{$M V E$} & 0.011 & 0.006 & 0.006 & 0.006 \\
\hline & -0.819 & -0.411 & -0.436 & -0.436 \\
\hline \multirow[t]{2}{*}{$N U M$} & -0.021 & 0.02 & 0.02 & -0.02 \\
\hline & $(-1.538)$ & -1.42 & -1.424 & $(-1.411)$ \\
\hline \multirow[t]{2}{*}{$L E G A L$} & -0.15 & -0.008 & 0 & -0.006 \\
\hline & $(-.640)$ & $(-.332)$ & $(-.002)$ & $(-.229)$ \\
\hline \multirow[t]{2}{*}{ SHRPROTECTION } & -0.002 & -0.002 & -0.001 & 0.015 \\
\hline & $(-.068)$ & $(-.071)$ & $(-.013)$ & -0.759 \\
\hline \multirow{2}{*}{$\operatorname{Adj} . R^{2}$} & 2093 & 2093 & 2093 & 2093 \\
\hline & 0.016 & 0.01 & 0.1 & 0.013 \\
\hline
\end{tabular}

The table contains regression results for the ADR control sample ForDisp measured as the standard deviation of analyst forecast standardized by the absolute value of the mean analyst forecast. In Model $1, U P=1$ for ADRs that upgrade and 0 - otherwise; $D O W N=1$ - for ADRs that downgraded and 0 - otherwise. In Model 2, $U P=1$ for ADRs that upgrade to Level 3, and 0 otherwise; $D O W N=1$ for ADRs that downgraded and 0 otherwise. In Model 3, $U P=$ 1 for ADRs that upgrade to Level 3, and 0 otherwise; $D O W N=1$ for ADRs that downgraded and 0 otherwise. In Model $4, U P=1$ for ADRs that upgrade to Level 2 or Level 3, and 0 otherwise.; $D O W N=1$ for ADRs that downgraded and 0 otherwise. Level $1=1$ - ADRs listed on level 1 and 0 -otherwise. Level $2=1$ - ADRs listed on level 2 and 0 -otherwise. Level $3=1$ - ADRs listed on level 3 and 0 -otherwise. Size is measured as the firm's total assets. Lev is measured as total assets/total liabilities. MVE is measured as the natural log of the ADR's market value of equity. NUM is defined as the number of $\mathrm{I} / \mathrm{B} / \mathrm{E} / \mathrm{S}$ analysts that report forecast estimates for each ADR firm. ForDisp Forecast dispersion measured as the standard deviation of analyst forecast standardized by the absolute value of the mean analyst forecast. Legal is a dummy variable that takes the value of 1 if the ADR's home country practices common law and 0 if civil law. Legal variables are from La Porta et al. [1998]. SHRPROTECTION is a dummy variable that takes the value of 1 if the ADR's home country has weak shareholder protection and 0 if strong shareholder protection. The t-value is reported in parentheses. $* * * * *$, and $*$ denote significance at 1,5 , and $10 \%$, respectively.

The results for Models 1, 2, 3, and 4 all showed negative coefficients for the UP sample. These negative but insignificant coefficients suggest that the improvement (decrease) in forecast dispersion is greater for ADRs that upgrade their listing level. The results for Models 1, 2, and 4 all showed positive coefficients for the DOWN sample. These positive but insignificant coefficients suggest that increase in forecast dispersion is greater for ADRs that downgrade their listing level.

Models 3 and 4 produced negative coefficients for Level II and Level III and a positive coefficient for Level I. These results however were not significant.

\subsection{Multivariate Regression Analysis -Forecast Accuracy - Change Sample}

Table 15 presents regression results for the change in forecast error measured as the absolute value of actual analyst forecast minus the mean analyst forecast standardized by the actual analyst forecast. In table 15, I separately run three regression models with different samples: (1) Model 1, CHANGE is an indicator variable that takes the value of 1 if the ADR Upgraded and 0 otherwise; (2) Model 2, CHANGE is an indicator variable that takes the value of 1if the ADR Upgraded to Level 3 only and 0 otherwise; (3) Model 3, CHANGE is an indicator variable that takes the value of 1 if the ADR Upgraded to Level 2 or Level 3, and 0 otherwise. The Change variable produced a negative coefficient for Models 1,2, and 3. These results indicate that there is a negative correlation between ADRs that upgrade and forecast error. This suggests that ADRs that upgrade their listing level have lower forecast error. However these results were only significant for Model 1 at the $10 \%$ level. I also find that firms that upgraded their listing level (model 1) and those that upgrade to a level III (model 2) originate from a civil law country and experience 0.437 and 0.573 less forecast 
error. ADRs that upgrade specifically to a level II or level III (model 3) originate from a civil law country and experience 1.068 times less forecast error. These results are significant at the $5 \%$ level.

Table 15. Multivariate Regression Analysis forecast accuracy

\begin{tabular}{|c|c|c|c|}
\hline \multicolumn{4}{|c|}{ Change Sample } \\
\hline \multicolumn{4}{|c|}{ Regression Analysis - $\Delta$ Forecast Error } \\
\hline & Model (1) & Model (2) & Model (3) \\
\hline \multicolumn{4}{|l|}{ Variables } \\
\hline Intercept & $\begin{array}{c}13.202 \\
(3.957)^{* * *}\end{array}$ & $\begin{array}{c}3.278 \\
(-3.767)^{* * *}\end{array}$ & $\begin{array}{c}6.128 \\
(3.630)^{* * *}\end{array}$ \\
\hline \multirow[t]{2}{*}{ CHANGE } & -0.065 & -0.051 & -0.023 \\
\hline & $(-1.675)^{*}$ & $(-1.300)$ & $(-.823)$ \\
\hline \multirow{2}{*}{ SIZE } & 0.054 & 0.056 & -0.003 \\
\hline & -1.213 & -1.252 & $(-.114)$ \\
\hline \multirow[t]{2}{*}{$L E V$} & -0.012 & -0.012 & -0.015 \\
\hline & $(-.303)$ & $(-.317)$ & $(-.523)$ \\
\hline \multirow[t]{2}{*}{$M V E$} & -0.044 & -0.042 & -0.035 \\
\hline & $(-.974)$ & $(-.947)$ & $(-1.228)$ \\
\hline \multirow[t]{2}{*}{$N U M$} & -0.001 & -0.002 & 0.014 \\
\hline & $(-.035)$ & $(-.043)$ & -0.49 \\
\hline \multirow[t]{2}{*}{ YEAR } & -0.0326 & -0.0442 & -0.0615 \\
\hline & $(0.02)^{* *}$ & $(0.03)$ & $(0.015)^{* *}$ \\
\hline \multirow[t]{2}{*}{$L E G A L$} & -0.437 & -0.573 & -1.068 \\
\hline & $(-2.91)^{* *}$ & $(-2.26)^{* *}$ & $(-2.85)^{* *}$ \\
\hline \multirow[t]{2}{*}{ SHRPROTECTION } & -0.392 & -0.453 & -0.767 \\
\hline & $(-2.56)^{* *}$ & $(-2.73)^{* *}$ & $(-2.82)$ \\
\hline$N$ & 448 & 448 & 448 \\
\hline Adj. $R^{2}$ & 0.1325 & 0.1318 & 0.142 \\
\hline
\end{tabular}

The table contains regression results for the change in forecast error measured as the absolute value of actual analyst forecast minus the mean analyst forecast standardized by the actual analyst forecast. In Model 1, CHANGE is an indicator variable that takes the value of 1 if the ADR Upgraded and 0 otherwise. In Model 2, CHANGE is an indicator variable that takes the value of 1 if the ADR Upgraded to Level 3 only and 0 otherwise. In Model 3, CHANGE is an indicator variable that takes the value of 1 if the ADR Upgraded to Level 2 or Level 3, and 0 otherwise. Size is measured as the firm's total assets. Lev is measured as total assets/total liabilities. MVE is measured as the natural log of the ADR's market value of equity. Num is defined as the number of $\mathrm{I} / \mathrm{B} / \mathrm{E} / \mathrm{S}$ analysts that report forecast estimates for each ADR firm. YEAR is a dummy variable that takes the place of 1 if the ADR changed its listing level after April 2002 and 0 otherwise. Legal is a dummy variable that takes the value of 1 if the ADR's home country practices common law and 0 if civil law. Legal variables are from La Porta et al. [1998]. SHRPROTECTION is a dummy variable that takes the value of 1 if the ADR's home country has weak shareholder protection and 0 if strong shareholder protection. The t-value is reported in parentheses. $* * * * *$, and $*$ denote significance at 1,5 , and $10 \%$, respectively.

The results also suggest that those ADRs that upgraded, especially to level III, originate from weak investor protection countries and experience 0.392 and 0.453 times less forecast error. These results are significant at the $5 \%$ level.

\subsubsection{Multivariate Regression Analysis - Number of Analyst Following}

\section{Change Sample}

Table 16 reports the impact of changes in listing level on the number of analyst following. In table 16, I separately run three regression models with different samples: (1) Model 1, CHANGE is an indicator variable that takes the value of 1 if the ADR Upgraded and 0 otherwise; (2) Model 2, CHANGE is an indicator variable that takes the value of 1if the 
ADR Upgraded to Level 3 only and 0 otherwise; (3) Model 3, CHANGE is an indicator variable that takes the value of 1 if the ADR Upgraded to Level 2 or Level 3, and 0 otherwise. The positive coefficient in Models 1, 2, and 3 for the Change variable indicate that there is a positive correlation between ADRs that upgrade and the number of analysts following. This suggests that ADRs that upgrade their listing level have more analysts following compared to those ADRs that downgraded. For Models 1, 2, 3, these results were significant for at the $10 \%, 5 \%$, and $1 \%$ level.

The results in table 16 also supports the hypothesis that ADRs from civil law countries and ADRs from weak investor protection countries would experience a higher net effect associated with a change of listing level. I find that firms from a civil law country with an ADR that upgraded their listing level have 0.0932 more analysts following the firm. Specifically, firms from a civil law country with an ADR that upgraded to a level III and those upgraded to a level II or level III have 0.1376 and 0.3992 more analysts following the firm.

Table 16. Multivariate Regression Analysis - Number of analyst's forecast

\begin{tabular}{|c|c|c|c|}
\hline \multicolumn{4}{|c|}{ Change Sample } \\
\hline & Model (1) & Model (2) & Model (3) \\
\hline \multicolumn{4}{|l|}{ Variables } \\
\hline \multirow[t]{2}{*}{ Intercept } & 3.666 & 3.618 & 2.351 \\
\hline & $(7.358)^{* * *}$ & $(7.398)^{* * *}$ & -9.91 \\
\hline \multirow[t]{2}{*}{ CHANGE } & 0.069 & 0.079 & 0.125 \\
\hline & $(1.810)^{*}$ & $(2.071)^{* *}$ & $(4.705)^{* * *}$ \\
\hline \multirow[t]{2}{*}{ SIZE } & 0.043 & 0.046 & -0.007 \\
\hline & -1.035 & -1.098 & $(-.267)$ \\
\hline \multirow[t]{2}{*}{$L E V$} & -0.018 & -0.017 & -0.026 \\
\hline & $(-.482)$ & $(-.468)$ & $(-.993)$ \\
\hline \multirow[t]{2}{*}{$M V E$} & 0.044 & 0.046 & -0.036 \\
\hline & -1.044 & -1.088 & $(-1.323)$ \\
\hline \multirow[t]{2}{*}{$Y E A R$} & 0.331 & 0.415 & -0.062 \\
\hline & $(0.082)$ & $(0.07)^{* *}$ & $(0.056)^{* *}$ \\
\hline \multirow[t]{2}{*}{$L E G A L$} & 0.0932 & 0.1376 & 0.3992 \\
\hline & $(1.963)^{*}$ & $(2.07)^{* *}$ & $(2.74)^{* * *}$ \\
\hline \multirow[t]{2}{*}{ SHRPROTECTION } & -1.7516 & -1.163 & -1.87 \\
\hline & $(0.0870)^{* *}$ & $(-0.096)^{* *}$ & $(-3.27)^{* *}$ \\
\hline$N$ & 448 & 448 & 448 \\
\hline Adj. $R^{2}$ & 0.1448 & 0.1542 & 0.1731 \\
\hline
\end{tabular}

Number of Analyst Coverage is for the years 1992-2010 and is defined as the number of I/B/E/S analysts that report forecast estimates for each ADR firm. In Model 1, CHANGE is an indicator variable that takes the value of 1 if the ADR Upgraded and 0 otherwise. In Model 2, CHANGE is an indicator variable that takes the value of 1if the ADR Upgraded to Level 3 only and 0 otherwise. In Model 3, CHANGE is an indicator variable that takes the value of 1if the ADR Upgraded to Level 2 or Level 3, and 0 otherwise. Size is measured as the firm's total assets. Lev is measured as total assets/total liabilities. MVE is measured as the natural $\log$ of the ADR's market value of equity. YEAR is a dummy variable that takes the place of 1 if the ADR changed its listing level after April 2002 and 0 otherwise. Legal is a dummy variable that takes the value of 1 if the ADR's home country practices common law and 0 if civil law. Legal variables are from La Porta et al. [1998]. SHRPROTECTION is a dummy variable that takes the value of 1 if the ADR's home country has weak shareholder protection and 0 if strong shareholder protection. The t-value is reported in parentheses. ${ }^{* *},{ }^{* *}$, and $*$ denote significance at 1,5 , and $10 \%$, respectively. 
The results also suggest that firms from a country with weak investor protection have 1.7516 more analysts following the firm. Specifically, firms from a weak investor protection country with an ADR that upgraded to a level III and those upgraded to a level II or level III have 1.163 and 1.87 more analysts following the firm.

\subsubsection{Multivariate Regression Analysis - Forecast Dispersion}

\section{Change Sample}

In table 17, I analyze the change in listing level on the information environment of ADRs by examining changes in the dispersion of analyst recommendations. Forecast dispersion is a proxy for differences in opinions about the value of the firm (Diether et al., 2002; Boheme et al., 2006) reports the impact of changes in listing level on the number of analyst following. Forecast dispersion measured as the standard deviation of analyst forecast standardized by the absolute value of the mean analyst forecast. In table 16, I separately run three regression models with different samples: (1) Model 1, CHANGE is an indicator variable that takes the value of 1 if the ADR Upgraded and 0 otherwise; (2) Model 2, CHANGE is an indicator variable that takes the value of 1if the ADR Upgraded to Level 3 only and 0 otherwise; (3) Model 3, CHANGE is an indicator variable that takes the value of 1 if the ADR Upgraded to Level 2 or Level 3, and 0 otherwise. According to the results, there were no significant differences in forecast dispersion between ADRs that upgraded or downgraded their listing level. The insignificant findings may be supported by the fact that new information could be interpreted differently. The relation between forecast dispersion and the information environment is still an empirical issue. According to Barron et al. (1998), forecast dispersion could actually increase with additional public information and decrease with additional private information. Additionally, Harris and Raviv (1993) documented that analysts hold different interpretations on new information that can result in analysts' belief about the firm deviating. They posit that analysts share common prior beliefs and receive the same information; however analysts may differ in the way they actually interpret this new information.

The number of analysts following however showed negative significant results. This was true for Models 1, 2, and 3 at the $1 \%$ level. This suggests that as the number of analysts following increase, forecast dispersion decreases.

The results in table 17 also supports the hypothesis that ADRs from civil law countries and ADRs from weak investor protection countries would experience a higher net effect associated with a change of listing level. I find that firms from a civil law country with an ADR that upgraded their listing level have 0.513 less forecast dispersion. This result was significant at the $5 \%$ level. Specifically, firms from a civil law country with an ADR that upgraded to a level III have 0.513 less forecast dispersion and those upgraded to a level II or level III have 0.843 less forecast dispersion. The results also suggest that firms from a country with weak investor protection have 0.765 less forecast dispersion. Specifically, firms from a weak investor protection country with an ADR that upgraded to a level II or level III have 0.836 less forecast dispersion. This result was significant at the $5 \%$ level.

Table 17. Multivariate Regression Analysis - Forecast Dispersion

\section{Change Sample}

Regression Analysis - $\Delta$ Forecast Dispersion

\begin{tabular}{rccc}
\hline & Model $(1)$ & Model (2) & Model (3) \\
Variables & & & -0.019 \\
Intercept & -0.118 & 0.066 & $(-.339)$ \\
& $(-1.761)$ & $(-1.660)$ & 0.002 \\
SHANGE & 0.044 & 0.037 & -0.047 \\
& -1.052 & -0.875 & -0.002 \\
LEV & 0.002 & 0.002 & $(-.043)$ \\
& -0.05 & -0.035 & -0.009 \\
MVE & -0.012 & -0.012 & $(-.254)$ \\
& $(-.292)$ & $(-.296)$ & 0.086 \\
NUM & 0.022 & 0.021 & $(2.387)^{* * *}$ \\
& -0.474 & -0.461 & -0.114 \\
YEAR & -0.124 & -0.123 & $(-3.241)^{* * *}$ \\
& $(-3.061)^{* * *}$ & $(-3.049)^{* * *}$ & -0.0217 \\
& -0.0192 & -0.106 & $(0.19)$
\end{tabular}




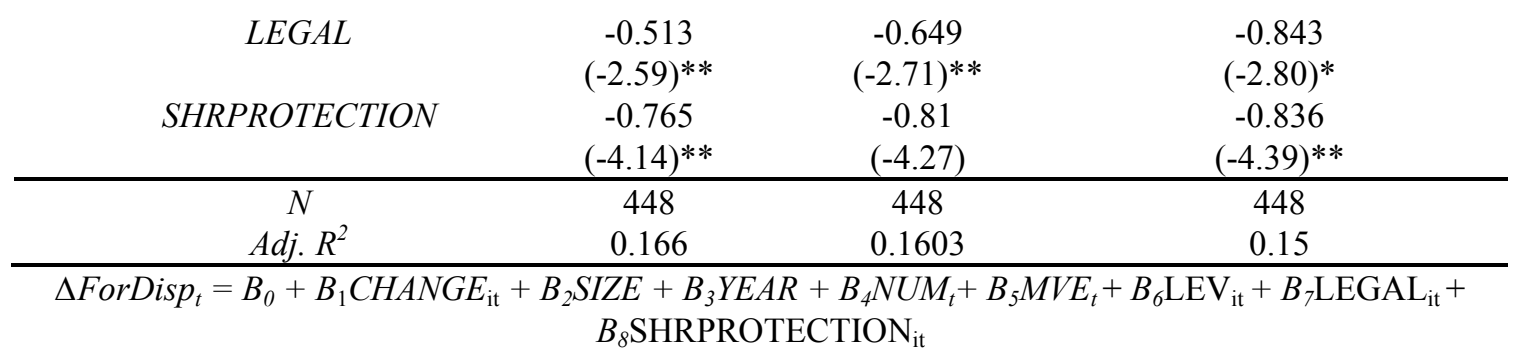

The table contains regression results for the change in forecast dispersion measured as the standard deviation of analyst forecast standardized by the absolute value of the mean analyst forecast. In Model 1, CHANGE is an indicator variable that takes the value of 1 if the ADR Upgraded and 0 otherwise. In Model 2, CHANGE is an indicator variable that takes the value of 1 if the ADR Upgraded to Level 3 only and 0 otherwise. In Model 3, CHANGE is an indicator variable that takes the value of 1 if the ADR Upgraded to Level 2 or Level 3, and 0 otherwise. Size is measured as the firm's total assets. Lev is measured as total assets/total liabilities. MVE is measured as the natural log of the ADR's market value of equity. Num is defined as the number of $\mathrm{I} / \mathrm{B} / \mathrm{E} / \mathrm{S}$ analysts that report forecast estimates for each ADR firm. YEAR is a dummy variable that takes the place of 1 if the ADR changed its listing level after April 2002 and 0 otherwise. Legal is a dummy variable that takes the value of 1 if the ADR's home country practices common law and 0 if civil law. Legal variables are from La Porta et al. [1998]. SHRPROTECTION is a dummy variable that takes the value of 1 if the ADR's home country has weak shareholder protection and 0 if strong shareholder protection. The t-value is reported in parentheses. $* * * * *$, and $*$ denote significance at 1,5 , and $10 \%$, respectively.

\section{Discussion, Limitations, and Conclusion}

In this study, I examine the change in ADR listing effects of U.S. cross-listed firms on the information environment for a sample of ADR firms. Prior research shows significant valuation effects of cross-listings in the United States. The literature thus far presents evidence to suggest that U.S. cross-listings offer substantial benefits. Additionally, cross-listing can improve investor recognition and enlarge a firm's investor base, and increase liquidity which could reduce the cost of capital (e.g., Merton, 1987; Karolyi, 1998; Foerster and Karolyi, 1999; Karolyi and Stulz, 2003).

Alternatively, it is possible that by just having an existing presence in the U.S. market improves the information of these foreign firms. Listings on Nasdaq, NYSE, or Amex require foreign firms to comply with U.S. Securities and Exchange Commission's (SEC) disclosure rules, which typically imply a substantial increase in disclosure and could manifest in a lower cost of capital (e.g., Verrecchia, 2001; Lambert, Leuz, and Verrecchia, 2007) and a decrease in information asymmetry. Their results support the functional convergence hypothesis, which suggest that cross-listed firms gain by moving from a poor quality information environment to one of increased enforcement, enhanced disclosure, and moderated litigation procedures (Coffee, 2002). This suggests that firms' information environment should be a function of cross-listing, as a firm is committing to an increased level of disclosure and scrutiny in order to comply with the SEC and GAAP.

The extant literature however provides little evidence on the mechanism(s) by which trading on a particular ADR listing level effects the information environment on these ADRs. Therefore, this study investigates whether the information environment of ADRs differ according the level by which the firm is listed and also I examine changes on the information environment when these ADRs decide to modify their listing level.

One important question is whether and to what extent cross-listing promotes an improvement in the information environment as the bonding hypothesis would suggest. Understanding this is paramount. This issue centers on the debate about the Sarbanes-Oxley Act and the proposed adoption of IFRS and its potential consequences on ADRs decision to cross-list.

To answer this question, I examine the four main levels of ADRs and analyze the impact of upgrading and downgrading the ADR listing level on the information environment of the ADRs as proxied by analysts' forecast. Specifically I examine whether ADRs that upgrade (or downgrade) their listing levels have increased (decreased) forecast accuracy, greater (less) analysts coverage/following, and less (greater) forecast dispersion.

I first examine the average forecast accuracy, number of analysts, and forecast dispersion when the ADR firm changed their listing level. I find that ADRs that upgraded experienced more forecast accuracy in their earnings forecast. Additionally, ADRs that upgraded experienced an increase in analyst coverage. I found no significant reduction in forecast dispersion between ADRs that upgraded or downgraded. 
I also examined home-country variables on the improved information environment of the ADRs. $L E G A L$ and SHHRPROTECTION were two measures to capture the level of information disclosure of the home country. I hypothesized that ADRs from civil law countries and ADRs from weak investor protection countries would experience a higher net effect associated with a change of listing level than ADRs from common law and strong shareholder protection countries. The results of this study support this hypothesis in that foreign firms from weaker legal systems would experience greater improvement in their information environment upon cross-listing in the U.S. Therefore, ADRs from civil law countries and those from weak investor protection experience more forecast accuracy, more analysts' following, and less forecast dispersion. These firms desire more access to capital and so they are willing to cross-list or upgrade to an ADR program that provides them these benefits. Thus, firms from these civil law and weak investor protection countries bond to the stringent rules and disclosure requirements of the U.S. in order to obtain more access to the capital markets and also to protect their shareholders.

This research also looks further into the discussion on the bonding hypothesis by examining whether the implementation of the Sarbanes-Oxley Act in 2002 influenced the ADR's choice of listing level. YEAR is a dummy variable equal to 1 if the ADR changed its listing level after SOX was enacted. I use April 24, 2002 as the date because it follows the Sarbanes-Oxley Act bill in the House (Litvak, 2007) Various U.S. regulatory and exchange rules may deter foreign firms from cross-listing on the U.S. exchanges. For example, to comply with SOX can be extremely costly for firms because they require more corporate governance and transparency. Thus, adhering to the rigorous rules of SOX can increase the costs of choosing to cross-list as a Level II and Level III. Although Level II and Level III programs incur the same costs, choosing to trade as a Level II ADR program may be less beneficial to foreign firms. Level II ADR firms are not permitted to raise capital by issuing IPOs; only Level III programs. Therefore, the benefits may not outweigh the cost for these Level II ADRs.

Therefore, foreign firms may be less likely to upgrade to a Level II or Level III during the post-SOX period. However, foreign firms may be more enticed to upgrade to a Level III program than a Level II program. Additionally, foreign firms may be more likely to downgrade their listing level to Level I or Level IV which allows these firms to avoid adhering to these strict rules while at the same time still reaping the rewards of having access to the U.S. capital markets.

The results indicated that firms that change their listing level after SOX downgraded their listing level to a Level I or Level IV because these firms are not required to comply with stringent rules but it still allows them to tap into the U.S. markets and raise capital.

To summarize, there seems to be significant effects stemming from the type of ADR listing and also the change in ADR listing in analysts' expectations for the different ADR type. However, only some of the ADR types show a significant difference in analysts forecast, forecast dispersion, and number of analysts' following. Thus, for ADRs cross-listing on the U.S. exchanges, the improvement in the information is generally attributable to mandatory compliance with U.S. SEC disclosure rules. However, even beyond the SEC increased enforcement which induces enhanced disclosure, there are cross-listing levels that require more stringent disclosure rules that only some ADRs (depending on their listing level) must adhere to.

The main caveat of this study is the sample size used. Because the study examines only the changes, the sample size only represents those firms that actually changed their listing level (448 firms) whereas the ADR universe, at the time this paper was written, had a record of over 4,407 ADRs that are cross-listed in the U.S. Second, while I interpret the evidence as indicating that cross-listing on specific levels increases the information environment of the firm, there may be some firms (that were not part of the study) that never changed their listing level but their information environment improved. It is suggested that future research examine the effects of ADR types without the intervening "change" factor.

\section{Acknowledgements}

I wish to thank Dr. Huey-Lian Sun, Chair of my dissertation committee, and the other committee members, Drs. Phyllis Keys, Yu Cong, and Vanthuan Nguyen for the invaluable feedback, suggestions, and guidance given during the course of this research.

\section{References}

Ang, James S., \& Yulong Ma. (1999). Transparency in Chinese stocks: A study of earnings forecasts by professional analysts. Pacific-Basin Finance Journal, 7(2), 129-155. http://dx.doi.org/10.1016/S0927-538X(99)00006-2

Ayres, B., \& R. Freeman. (2001). Evidence that Analysts and Institutions Increase the Returns- Earnings Relationship. Working Paper, University of Texas. 
Bailey, W., Karolyi, A., \& Salva, C. 2006). The economic consequences of increased disclosure: Evidence from international cross-listings. Journal of Financial Economics, 81, 175-213. http://dx.doi.org/10.1016/j.jfineco.2005.06.002

Baker, H., Nofsinger, J., \& Weaver, D. (2002). International cross-listing and visibility. Journal of Financial and Quantitative Analysis, 37, 495-521. http://dx.doi.org/10.2307/3594990

Ball, R. (2001). Infrastructure Requirements for an Economically Efficient System of Public Financial Reporting and Disclosure. Brookings-Wharton papers on Financial Services 127-182.

Ball, R., Kothari, S.P., \& Robin, A. (2000). The effect of international institutional factors on properties of accounting earnings. Journal of Accounting and Economics, 29, 1-51. http://dx.doi.org/10.1016/S0165-4101(00)00012-4

Bank of New York American Depositary Receipt Division, New York, NY. Retrieved from $\mathrm{http}: / /$ www.bankofny.com/adr

Barron, O., Kim, O., Lim, S., \& Stevens, D. (1998). Using analysts' forecasts to measure properties of analysts' information environment. The Accounting Review, 73, 421-433.

Barry, C.B., \& Brown, S.J. (1985). Differential information and security market equilibrium. Journal of Financial and Quantitative Analysis, 20, 407-422. http://dx.doi.org/10.2307/2330758

Basu, S, Leeseok, H., \& Ching-Lih, J. (1998). International variations in accounting measurement rules and analysts earnings forecasts errors. Journal of Business, Finance and Accounting, 25(9-10), 1207-1246. http://dx.doi.org/10.1111/1468-5957.00234

Bhushan, R. (1989). Firm characteristics and analyst following. Journal of Accounting and Economics, 11(2-3), 255-275. http://dx.doi.org/10.1016/0165-4101(89)90008-6

Boheme, R., Danielsen, B., \& Sorescu, S. (2006). Short-sale constraints, differences of opinion, and overvaluation. Journal of Financial and Quantitative Analysis, 41, 455-487. http://dx.doi.org/10.1017/S0022109000002143

Boubakri, Narjess, Cosset, Jean-Claude, \& Samet, Anis. (2010). The choice of ADRs. Journal of Banking and Finance, 34, 2077-2095. http://dx.doi.org/10.1016/j.jbankfin.2010.01.016

Bowen R.M., Davis A.K., \& Matsumoto D.A. (2002). Do conference calls affect Analysts' Forecasts? The Accounting Review, 77(2), 285-316. http://dx.doi.org/10.2308/accr.2002.77.2.285

Brennen, Michael J., \& Patricia J. Hughes. (1991). Stock prices and the supply of information, Journal of Finance, 46, 1665-1691. http://dx.doi.org/10.1111/j.1540-6261.1991.tb04639.x

Campbell, J. (1996). Understanding risk and return, Journal of Political Economy, 104, 298-345. http://dx.doi.org/10.1086/262026

Cantale, S. (1996). The choice of a foreign market as a signal. Working paper, Tulane University, New Orleans, MI.

Coffee, J. (1999). The future as history: the prospects for global convergence in Corporate Governance and its Implications. Northwestern University Law Review, 93, 641-708. http://dx.doi.org/10.2139/ssrn.142833

Coffee, J. (2002). Racing towards the top? The impact of cross-listings and stock market competition on international corporate governance. Columbia Law Review, 102, 1757-1831. http://dx.doi.org/10.2307/1123661

Das, S., \& S. Saudagaran. (1998). Accuracy, Bias, and dispersion in analysts' earnings forecasts: The case of cross-listed foreign firms. Journal of International Financial Management and Accounting, 9, 16-33. http://dx.doi.org/10.1111/1467-646X.00028

Diamond, D., \& Verrecchia, R. (1991). Disclosure, Liquidity, and the Cost of Capital. The Journal of Finance, 46(4), 1325-1359. http://dx.doi.org/10.1111/j.1540-6261.1991.tb04620.x

Diether, K., Malloy, C., \& Scherbina, A. (2002). Differences of opinion and the cross-section of stock returns. Journal of Finance, 57, 2113-2141. http://dx.doi.org/10.1111/0022-1082.00490

Doidge, Craig, G. Andrew Karolyi, \& René M. Stulz. (2004). Why are foreign firms listed in the U.S. worth more? Journal of Financial Economics, 71(2), 205-238. http://dx.doi.org/10.1016/S0304-405X(03)00183-1

Doidge, Craig, A.George Karolyi, \& Rene M. Stulz. (2009). Has New York become less competitive than London in global markets? Evaluating foreign listing choices over time. Journal of Financial Economics, 91, 253-277. http://dx.doi.org/10.1016/j.jfineco.2008.02.010 
Engel, E., Hayes, R., \& Wang, X. (2007). The Sarbanes-Oxley Act and firms' going-private decisions. Journal of Accounting and Economics, 44, 116-145. http://dx.doi.org/10.1016/j.jacceco.2006.07.002

Errunza, V., \& Miller, D. (2000). Market Segmentation and the Cost of Capital in International Equity Markets. Journal of Finance and Quantitative Analysis, 35(4), 577-600. http://dx.doi.org/10.2307/2676256

Fama, Eugene F., \& Kenneth R. French. (1992). The cross-section of expected stock returns. Journal of Finance, 47, 427-465. http://dx.doi.org/10.1111/j.1540-6261.1992.tb04398.x

Fama, Eugene F., \& Kenneth R. French. (1993). Common risk factors in the returns on stocks and bonds. Journal of Financial Economics, 33, 3-56. http://dx.doi.org/10.1016/0304-405X(93)90023-5

Fanto, J. A., \& R. S. Karmel. (1997). A report on the attitudes of foreign companies regarding a US listing. Stanford Journal of Law, Business and Finance, 3, 51-83.

Foerster S., \& A. Karolyi. (1999). The effects of market segmentation and investor recognition on asset prices: evidence from foreign stocks listing in the U.S. Journal of Finance, 54, 981-1014.

Francis, J., D. Nanda, \& Wang, X. (2006). Re-examining the Effects of Regulation Fair Disclosure Using Foreign Listed Firms to Control for Concurrent Stocks. Journal of Accounting \& Economics, 41, 271-292. http://dx.doi.org/10.1016/j.jacceco.2006.03.002

Fuerst, O. (1998). A theoretical analysis of the investor protection regulations argument for global listing of stocks. Working paper, Yale University, New Haven, CN.

Glosten, L.R., \& P.R. Milgrom. (1985). Bid, Ask and Transaction Prices in a Specialist Market with Heterogeneously Informed Traders. Journal of Financial Economics, 14, 71-100. http://dx.doi.org/10.1016/0304-405X(85)90044-3

Harris, M., \& Raviv, A. (1993). Differences of opinion make a horse race. Review of Financial Studies, 6, 473-494. http://dx.doi.org/10.1093/rfs/5.3.473

Healy, P., Hutton, A., \& Palepu, K. (1999). Stock performance and intermediation changes surrounding sustained increases in disclosure. Contemporary Accounting Research, 16, 485-520. http://dx.doi.org/10.1111/j.1911-3846.1999.tb00592.x

Healy, P., \& Palepu, K. (2001). Information asymmetry, Corporate Disclosure, and the Capital Markets: A Review of the Empirical Disclosure Literature. Journal of Accounting and Economics, 31, 405-440. http://dx.doi.org/10.1016/S0165-4101(01)00018-0

Hope, Ole-Kristian. (2003). Disclosure practices, enforcement of accounting standards, and analysts' forecast accuracy: An international study. Journal of Accounting Research, 41(2), 235-272. http://dx.doi.org/10.1111/1475-679X.00102

Hung, M. (2001). Accounting standards and value relevance of earnings: An international analysis. Journal of Accounting and Economics, 30(3), 401-420. http://dx.doi.org/10.1016/S0165-4101(01)00011-8

Karolyi, A. (1998). Why do companies list shares abroad? A survey of the evidence and its managerial implications, Financial Markets, Institutions, and Instruments. Blackwell Publishers, Boston.

Karolyi, G. A., \& R. M. Stulz. (2003). Are Assets Priced Locally or Globally?. In G. Constantinides, M. Harris and R. Stulz (Eds.), Handbook of the Economics of Finance. Elsevier Science, Amsterdam, The Netherlands.

Karolyi, G. A. (2006). The world of cross-listings and cross-listings of the world: challenging conventional wisdom. Review of Finance, 10, 1-54. http://dx.doi.org/10.1007/s10679-006-6980-8

Karpoff, Lee, D., \& Martin, G. (2008). The Cost to firms of Cooking the Books. Journal of Financial and Quantitative Analysis, 43, 581-612. http://dx.doi.org/10.1017/S0022109000004221

Khanna, Tarun, \& Krishna Palepu. (2000). Is group affiliation profitable in emerging markets? An analysis of diversified Indian business groups. The Journal of Finance, 55(2), 867. http://dx.doi.org/10.1111/0022-1082.00229

Kim, O., \& Verrecchia, R. (1991). Trading Volume and Price Announcements to Public Announcements. Journal of Accounting Research, 29(2), 302-321. http://dx.doi.org/10.2307/2491051

Lambert, R., Leuz, C., \& Verrecchia, R. (2007). Accounting Information, Disclosure, and the Cost of Capital. Journal of Accounting Research, 45(2), 385-420. http://dx.doi.org/10.1111/j.1475-679X.2007.00238.x 
Lang, M., \& Lundholm, R. (1993). Cross-sectional determinants of Analysts ratings of corporate disclosures. Journal of Accounting Research, 31, 246-271. http://dx.doi.org/10.2307/2491273

Lang, M., \& Lundholm, R. (1996). Corporate disclosure policy and analyst behavior. The Accounting Review, 71, 467-492.

Lang, Mark H., Karl V. Lins, \& Darius P. Miller. (2003). ADRs, analysts, and accuracy: Does cross listings in the U.S. improve a firm's information environment and increase market value? Journal of Accounting Research, 4l(2), 317-345. http://dx.doi.org/10.1111/1475-679X.00106

Lang, M, Lins, K., \& Miller, D. (2004). Concentrated control, analyst following, and valuation: Do Analyst matter most when investors are protected least? Journal of Accounting Research, 42(3), 589-624. http://dx.doi.org/10.1111/j.1475-679X.2004.t01-1-00142.x

Lang, M., Raedy, J., \& Wilson, W. (2006). Earnings management and cross-listing: Are reconciled earnings comparable to US earnings? Journal of Accounting and Economics, 42, 255-283. http://dx.doi.org/10.1016/j.jacceco.2006.04.005

La Porta, Rafael, Florencio Lopez-De-Silanes, Andrei Shleifer, \& Robert W. Vishny. (1997). Working paper, National Bureau of Economic Research.

La Porta, Rafael, Florencio Lopez-De-Silanes, Andrei Shleifer, \& Robert W. Vishny. (1998). Law and Finance, Journal of Political Economy, 106(6), 1113-1155. http://dx.doi.org/10.1086/250042

La Porta, R., F. Lopez-de-Silanes, A. Shleifer, \& R. Vishny. (2000), Investor protection and corporate governance. Journal of Financial Economics, 58, 3-27. http://dx.doi.org/10.1016/S0304-405X(00)00065-9

Leuz, C., Triantis, A., \& Wang, T. (2008). Why do Firms go Dark? Causes and Economic Consequences of Voluntary SEC deregistrations. Journal of Accounting and Economics, 45, 181-208. http://dx.doi.org/10.1016/j.jacceco.2008.01.001

Licht, A. (2003). Cross-listing and Corporate Governance: Bonding or Avoiding? Chicago Journal of International Law, 4, 141-163. http://dx.doi.org/10.2139/ssrn.382660

Lins, K., D, Strickland, \& M. Zenner. (2000). Do non-U.S. firms issue equity on U.S. stock exchanges to relax capital constraints? Working paper, University of North Carolina, Chapel Hill, NC.

Lins, K., Strickland, D., \& Zenner, M. (2005). Do non-U.S. firms issue equity on U.S. exchanges to relax capital constraints? Journal of Financial and Quantitative Analysis, 40, 109-133. http://dx.doi.org/10.1017/S0022109000001769

Litvak, K. (2007). The effect of the Sarbanes-Oxley Act on non-US companies cross-listed in the US. Journal of Corporate Finance, 13, 195-228. http://dx.doi.org/10.1016/j.jcorpfin.2007.03.002

Marosi, A., \& Massoud, N. (2007). Why do firms go dark? Journal of Financial and Quantitative Analysis, 42, 421-442. http://dx.doi.org/10.1017/S0022109000003331

Merton, R. (1987). A Simple Model of Capital Equilibrium with Incomplete Information. The Journal of Finance, 42(3), 483-510. http://dx.doi.org/10.1111/j.1540-6261.1987.tb04565.x

Miller, D. P. (1999). The market reaction to international cross-listing: Evidence from depositary receipts. Journal of Financial Economics, 51, 103-123. http://dx.doi.org/10.1016/S0304-405X(98)00045-2

Mitto, U. (1992). Managerial Perceptions of the Net Benefits of Foreign Listing: Canadian Evidence. Journal of International Financial Management and Accounting, 4(1), 40-62. http://dx.doi.org/10.1111/j.1467-646X.1992.tb00021.x

Modigliani, F, \& Miller, M H. (1958). The Cost of Capital, Corporation Finance, and the Theory of Investment. American Economic Review, 48(3), 261-97.

Moel, A. (1999). The role of information disclosure on stock market listing decisions: the case of foreign firms listing in the U.S. Working paper, Harvard Business School, Boston, MA.

Pagano, M. Roel, A., \& Zechner, J. (2002). The geography of equity listing: why do companies list abroad? Journal of Finance, 57, 2651-2694. http://dx.doi.org/10.1111/1540-6261.00509

Reese, W., \& M. Weisbach. (2001). Protection of minority shareholder interests, cross-listings in the United States, and subsequent equity offerings. Working paper, NBER, Cambridge, MA 
Reese, William Jr., Weisbach, \& Michael S. (2002). Protection of Minority Shareholders Interest, Cross-Listings in the United States and Subsequent Equity Offerings. Journal of Financial Economics. http://dx.doi.org/10.1016/S0304-405X(02)00151-4

Sarkissian, S., \& Schill, M. (2006). Are there permanent valuation gains to overseas listing? Evidence from market sequencing and selection. Review of Financial Studies, forthcoming.

Saudagaran, Shahrokh M., \& Meek, Gary K. (1997). A Review on the Relationship between International Capital Markets and Financial Reporting by Multinational Firms. Journal of Accounting Literature, 16, 127-159.

Siegel, J. (2001). Can foreign firms bond themselves effectively by submitting to U.S. law? MIT Working paper, Cambridge, MA.

Siegel, J. (2005). Can foreign firms bond themselves effectively by renting U.S. securities law? Journal of Financial Economics, 75, 319-359. http://dx.doi.org/10.1016/j.jfineco.2004.02.001

Stulz, R. M. (1999). Globalization, corporate finance, and the cost of capital. Journal of Applied Corporate Finance, 12, 8-25. http://dx.doi.org/10.1111/j.1745-6622.1999.tb00027.x

The Exchange. (2005, October).

Verrecchia, R. E. (2001). Essays on Disclosure. Journal of Accounting \& Economics, 32(1-3), 97-180. http://dx.doi.org/10.1016/S0165-4101(01)00025-8

Witmer, J. (2006). Why do firms cross-delist? An examination of the determinants and effects of cross-delisting, Queen's University working paper.

Zhu, Hong, \& Small, Ken. (2007). Has Sarbanes-Oxley Led to a Chilling in the U.S. Cross-Listing Market? The CPA Journal, 77(3).

Zingales, L. (2006). Is the U.S. capital market losing its competitive edge? Journal of Economic Perspectives forthcoming.

\section{Notes}

Note 1. See "The depositary receipt markets: The year in review" - 2006, Bank of New York.

Note 2. The respective websites are as follows: http://www.adrbny.com/, http://wwss.citissb.com/adr/www/(Universal Issuance Guide), http://www.adr.db.com/, and http:// www.adr.com/. 